\title{
Benstonea Callm. \& Buerki (Pandanaceae): characterization, circumscription, and distribution of a new genus of screw-pines, with a synopsis of accepted species
}

\author{
Martin W. Callmander, Porter P. Lowry II, Félix Forest, Dion S. Devey, Henk Beentje \& Sven Buerki
}

This article is dedicated to Benjamin Clemens Stone

\begin{abstract}
CALLMANDER, M. W., P. P. LOWRY II, F. FOREST, D. S. DEVEY, H. BEENTJE \& S. BUERKI (2012). Benstonea Callm. \& Buerki (Pandanaceae): characterization, circumscription, and distribution of a new genus of screwpines, with a synopsis of accepted species. Candollea 67: 323-345. In English, English and French abstracts.

Pandanaceae, a palaeotropical monocot family of c. 700 species, comprises four currently recognized genera: Freycinetia Gaudich., Martellidendron (Pic. Serm.) Callm. \& Chassot, Pandanus Parkinson and Sararanga Helms. Within Pandanus (c. 500 spp.), species of sect. Acrostigma Kurz [one of four sections comprising subg. Acrostigma (Kurz) B. C. Stone] possess highly distinctive morphological features (viz. sharp spiniform, linear styles with the stigmatic groove on the abaxial side of the style and a staminate flower reduced to 1 to 3 stamens) shared with two other species (likewise belonging to subg. Acrostigma but originally placed in sect. Fusiforma B. C. Stone) that separate them from all other congeners. Based on morphology, biogeography, and recent inferences from plastid DNA sequence data, we place these distinctive species in a new genus, Benstonea Callm. \& Buerki, making the necessary new combinations for the 50 recognized species, accompanied by six lectotypifications, one epitytification and two neotypifications, and placing seventeen names in synonymy. A generic key is provided to facilitate distinguishing Benstonea from the four other genera of Pandanaceae. Comments are provided on the distribution, ecology and typification of each accepted species.
\end{abstract}

\section{Key-words}

PANDANACEAE - Benstonea - Pandanus - Pandanus sect. Acrostigma - SE Asia - Taxonomy - Typification

\begin{abstract}
Résumé
CALLMANDER, M. W., P. P. LOWRY II, F. FOREST, D. S. DEVEY, H. BEENTJE \& S. BUERKI (2012). Benstonea Callm. \& Buerki: caractérisation, délimitation, distribution et taxonomie d'un nouveau genre de Pandanaceae, avec un synopsis des espèces acceptées. Candollea 67: 323-345. En anglais, résumés anglais et français.
\end{abstract}

La famille des Pandanaceae est une famille de monocotylédones paléotropicales comprenant c. 700 espèces et incluant actuellement quatre genres: Freycinetia Gaudich., Martellidendron (Pic. Serm.) Callm. \& Chassot, Pandanus Parkinson et Sararanga Helms. Dans le genre Pandanus (env. 500 espèces), les espèces de la sect. Acrostigma Kurz [une des quatre sections comprises dans le subg. Acrostigma (Kurz) B. C. Stone] possèdent des caractères résolument spécifiques, c'est-à-dire des styles spiniformes et tranchants avec une zone stigmatique sur la face abaxiale du style ainsi qu'une fleur mâle réduite à 1 à 3 étamines. Ces caractères sont partagés avec deux autres espèces appartenant aussi au subg. Acrostigma mais placées originellement dans la sect. Fusiforma B. C. Stone, les séparant de toutes les autres espèces de la famille. En référence à la morphologie, la biogéographie, et les récentes inférences des données de l'ADN chloroplastique, nous plaçons ces espèces distinctives dans un nouveau genre, Benstonea Callm. \& Buerki. Les nouvelles combinaisons nécessaires aux 50 espèces reconnues de ce nouveau genre sont accompagnées de six lectotypifications, une épitypification et deux néotypifications. Dix-sept espèces sont aussi nouvellement placées en synonymie. Une clé de détermination générique est fournie pour faciliter la distinction de Benstonea des quatre autres genres de Pandanaceae. Des commentaires sont fournis sur la distribution, l'écologie et la typification de chaque espèce acceptée.

\footnotetext{
Addresses of the authors: MWC: Missouri Botanical Garden, P.O. Box 299, St. Louis, MO, 63166-0299, U.S.A. and Conservatoire et Jardin botaniques de la Ville de Genève, CP 60, CH-1292 Chambésy, Switzerland. E-mail: martin.callmander@mobot.org

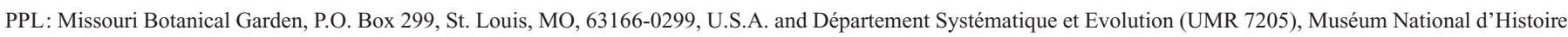
Naturelle, case postale 39, rue Cuvier 57, 75231 Paris (Cedex) 05, France.
}

FF, DSD, SB: Jodrell Laboratory, Royal Botanic Gardens, Kew, Richmond, Surrey, TW9 3DS, United Kingdom.

HB: Herbarium, Library, Art \& Archives, Royal Botanic Gardens, Kew, Richmond, Surrey, TW9 3DS, United Kingdom. 


\section{Introduction}

The screw-pine family, Pandanaceae, is a paleotropical group of arborescent or lianoid dioecious monocotyledonous plants, including c. 700 species traditionally assigned to four genera: Pandanus Parkinson (c. 500 species), Freycinetia Gaudich. (c. 200 species), Martellidendron (Pic. Serm.) Callm. $\&$ Chassot (six species) and Sararanga Hemsl. (two species) (StONE \& al., 1998; CALLMANDER \& al., 2003; Buerki \& al., 2012). Freycinetia occurs in SE Asia, the Pacific Islands and Australasia, and is characterized by its liana habit, multi-ovulate carpels and berry fruits (STONE, 1990). Martellidendron has a narrow range in Madagascar and the granitic Seychelles (Mahé and Praslin islands), and includes tree species characterized by potentially bisexual flowers (presence of carpellodia and staminodia in the staminate and the pistillate flowers, respectively), drupaceous fruit (mesocarp extending between the seed locules) and distinctive pollen morphology (3-layered pollen exine with an incomplete tectum; see CAllmander, 2000, 2001; CAllmander \& al., 2003). Sararanga is restricted to the Philippines, New Guinea and the Solomon Islands, and harbours large tree species that can be distinguished from other Pandanaceae by their paniculate inflorescences and flowers with a perianth (HuYNH, 2001). Finally, Pandanus has the broadest geographical distribution of the four genera, occurring in the paleotropics from West Africa eastward to Hawaii, and includes species of trees and shrubs. It is characterized by its pistillate flowers with one to several carpels, partially or entirely united; a stigma ranging from flat to spiniform, and arranged in various positions at the apex of the drupe; and staminate flowers with numerous stamens organized around a stemanophore or rarely free (see HUYNH, 1982). To accommodate this wide morphological variability found within Pandanus and to simplify identification, an elaborate infra-generic classification system has been developed in which eight subgenera (STONE, 1974; HUYNH, 1991; see Table 1 in BuERKI \& al., 2012) and 86 sections (Stone, 1974; St. John, 1975; Huynh, 1975, 1976, 1977, 1979, 1980; CALlmander \& al., 2001; LAIVAO \& al., 2006) are currently recognized.

Despite decades of work by several specialists, including B. C. Stone and K.-L. Huynh, the taxonomy of Pandanaceae, and in particular of Pandanus, still presents many challenges. Relationships among and within the genera are not well understood, and species identification is often problematic, even for experienced botanists. The time has now come to incorporate evidence from molecular inferences and biogeography in an effort to refine generic and infra-generic delimitations, especially within Pandanus. Stone (1990) questioned whether this large, polymorphic genus represented a natural (i.e., monophyletic) assemblage, given the distinctive morphology of several groups he recognized as subgenera, in particular subg.
Martellidendron (Pic. Serm.) B. C. Stone and subg. Acrostigma (Kurz) B. C. Stone. Subsequent work has confirmed that the species historically assigned to the subg. Martellidendron represented a distinct clade, which led to its recognition as a separate genus (CALLMANDER \& al., 2003). In the present paper we explore the phylogenetic relations of Pandanus subg. Acrostigma and consider the taxonomic and nomencatural implications.

Stone $(1974,1978,1983 a)$ distinguished Pandanus subg. Acrostigma based on several morphological characters of both the pistilate and staminate flowers, in particular the presence of stigmatic grooves on the abaxial side of the style and a reduction of the stamens. This subgenus, as circumscribed by STONE (1978, 1983a, 1983c, 1993), includes four sections: sect. Acro stigma (Kurz) B. C. Stone (type: P. affinis Kurz, c. 60 spp.), sect. Epiphytica Martelli (type: P. epiphyticus Martelli, 1 sp.), sect. Fusiforma H. St. John (type: P. dumetorum Holttum \& H. St. John, 5 spp.), and sect. Pseudoacrostigma B. C. Stone (type: P. platystigma Martelli, 2 spp.).

Pandanus sect. Acrostigma is currently divided into eight subsections based on various vegetative and reproductive characters, in particular habit (epiphytes or shrubs), presence or absence of prickles on the apical part of the ventral pleats, whether the distal part of pileus is smooth or scabrid, and the shape of the syncarp (cylindric to globose). Despite the diversity of the section, it nevertheless appears to form a natural group characterized by carpels that are consistently free (forming one-seeded drupes), a sharp, linear stigma always positioned on the abaxial side of the style, and staminate flowers reduced to a single stamen, or in triads, free or very slightly joined at the base.

Pandanus epiphyticus, the sole member of Pandanus sect. Epiphytica, is a massive epiphytic species (sometimes also growing on sandstone hills) found in Peninsular Malaysia and Borneo. Its morphology is unique, with a massive infructescence bearing up to nine sub-cylindric syncarps and small ovate stigmas (Fig. 1A, 1B). According to StONE (1971a: 143), "Its true relationship remains to be discovered".

Pandanus sect. Pseudoacrostigma, the third section included in Pandanus subg. Acrostigma, was described by Stone (1971a) to accommodate $P$. platystigma and was later expanded to include a subsequently described species, $P$. ornithocephalus B. C. Stone. The syncarp of P. platystigma (Fig. 1C) is dark red and fleshy, a character unknown elsewhere in Pandanus subg. Acrostigma, as circumscribed by STONE (1974). Furthermore, the stigmas are flat and reniform, which contrasts with other members of the subgenus. Pandanus ornithocephalus, know only from one collection in the Indonesian part of New Guinea (West Papua), bears styles with a swollen base with an oblique stigma (Stone, 1978; JeBB, 1992: 30). Its taxonomic position remains unclear, but unlike $P$. platystigma, it does not seem to 

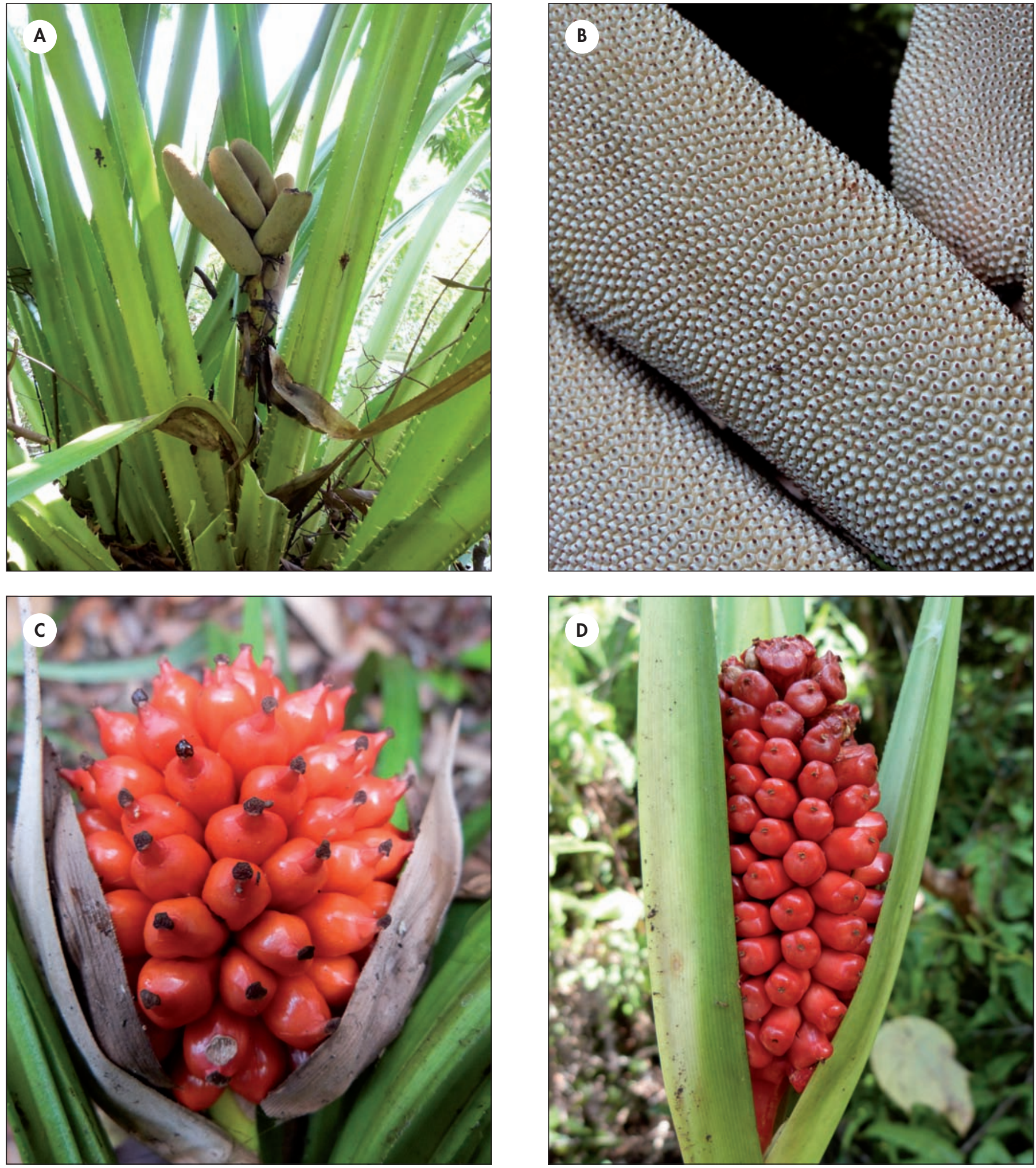

Fig. 1. - General habit, infructescences and details of stigmas of species of Pandanus sect. Epiphytica Martelli (A-B) and Pseudoacrostigma B. C. Stone (C-D). A-B. Pandanus epiphyticus Martelli; C. Pandanus platystigma Martelli ; D. Pandanus pugnax B. C. Stone.

[Photos: M. W. Callmander] 
bear fleshy fruits. Pandanus pugnax B. C. Stone, a species only tentatively assigned to Pandanus sect. Acrostigma as an incertae sedis entity by STONE $(1978,1993)$ because the fertile portion of its type (Meijer SAN 23289) appears to have been lost, was recently re-collected in Borneo by two of the authors of the present paper (SB and MWC; Callmander \& al. 1035). This new material shows that $P$. pugnax bears a terminal sub-elliptic syncarp $($ c. $4.5 \times 10 \mathrm{~cm})$ on a very long $($ c. $85 \mathrm{~cm})$ and narrow (c. $1.3 \mathrm{~cm}$ ) peduncle, a distinctive combination of character in Pandanus. The fruit is dark red and fleshy (Fig. 1D) as in P. platystigma, and its placement in Pandanus sect. Pseudoacrostigma thus seems appropriate.

Members of Pandanus sect. Fusiforma, the fourth component of STONE's (1974) Pandanus subg. Acrostigma, have distinctive leaves, which are exceedingly hard, very long (up to $8 \mathrm{~m}$ ) and wide (up to $8 \mathrm{~cm}$ ), a caespitose soboliferous habit, and drupes that have a pyramidal tip with an acute, rostriform stigma. On the basis of their stigmatic structure, however, the five species originally placed in Pandanus sect. Fusiforma (viz., P. biplicatus H. St. John, $P$. dumetorum, $P$. pachyphyllus Merr., P. saint-johnii B. C. Stone and P. soboliferus B. C. Stone) may well be allied to Pandanus sect. Acrostigma given the position of their stigmatic groove, as seen particularly well in P. pachyphyllus, which was originally placed by STONE in Pandanus sect. Fusiforma (1968, 1974, 1978) but later transferred to Pandanus sect. Acrostigma (Stone, 1993). Pandanus biplicatus, also initially placed in Pandanus sect. Fusiforma by STONe $(1968,1974,1978)$, may likewise be related to the members of Pandanus sect. Acrostigma considering its sharp, linear stigma.

One last species, Pandanus microglottis B. C. Stone, endemic to the Mulu National Park in Sarawak (Borneo), was surprisingly placed in Pandanus sect. Acrostigma by STONE (1982b, 1993). It stands out, however, because it bears short appressed styles that are ovate in shape (STONE, 1982b: 35, Tab. 7), a feature not found in any other member of the section. The relationships of this species, only known from the type collection, remain unclear, and additional gatherings, in particular of staminate material, will be needed to assess its taxonomic position.

Based on personal observations and familiarity with Pandanus throughout nearly all its geographic range, we have discerned that the group of species characterized by having the stigma consistently positioned on the abaxial side of a sharp, linear style stands out from all other Pandanus. This group corresponds to Pandanus sect. Acrostigma (with the exception of $P$. microglottis, which its relationship remains to be assessed) and also includes at least two species initially placed in Pandanus sect. Fusiforma sensu STONE (1968, 1974) (see above). This interpretation was supported by a recent plastid phylogenetic analysis of Pandanaceae (BUERKI \& al., 2012), which revealed five major clades within the family corresponding to Sararanga, Freycinetia, Martellidendron, Pandanus sect. Acrostigma, and the remaining species of Pandanus, including its type, P. tectorius Parkinson (Fig. 2) (BUERKI \& al., 2012). The distinctive nature of Pandanus sect. Acrostigma revealed by morphology and molecular data is further supported by the fact that the group exhibits a coherent biogeographic distribution ranging from India to the South Pacific, with high species richness in South East Asia (especially Borneo and Peninsular Malaysia; Fig. 3).

Based on these findings, we propose the new generic name Benstonea Callm. \& Buerki to accommodate the group comprising Pandanus sect. Acrostigma, as defined by STONE (1974) and modified above. A new name is required because Acro stigma O. F. Cook \& Doyle is a validly published genus of Arecaceae. Benstonea is defined by its sharp spiniform styles with stigmatic grooves consistently placed on the abaxial side of the style (vs always adaxial in Pandanus, as redefined by the exclusion of the species placed in our new genus), staminate flowers reduced to a single stamen or in triads that are free or very slightly joined at the base (vs connate, borne on a stemonophore, rarely free) and an epiphytic to mainly acaulescent shrubby habit (vs mainly small to large trees). A complete synopsis of Benstonea, including distribution, typification and synonymy of each of the 50 currently recognized species, is presented below. Nomenclatural notes are also provided for some species. Seventeen new synonymies are proposed and lectotypes are designated for six names, along with one epitype and two neotypes. We also provide an updated key to the five genera of Pandanaceae now recognized. Appendix 1 includes a complete list of synonyms for each of the accepted names in Benstonea.

\section{Taxonomic treatment}

Key to the genera of Pandanaceae (adapted from STONE, 1974; STONE \& al., 1998)

1. Pistillate inflorescence (infructescence) a panicle; leaves in 4 spiral rows; flowers with a perianth-like cupule ........

Sararanga

1a. Pistillate inflorescence (infructescence) a cephalium or a raceme or pseudo-umbel of cephalia; leaves in 3 spiral rows; flowers without a perianth-like cupule ................ 2

2. Liana; fruit a berry; carpels multi-ovulate (ovules much more numerous than 3 ); seeds generally free and germinating outside the fruit

Freycinetia

2a.

Acaulescent shrubs to large trees; fruit a drupe with a hard bony endocarp; carpels uniovulate, rarely 2-3 ovulate; seed bound to endocarp and always germinating within the fruit 


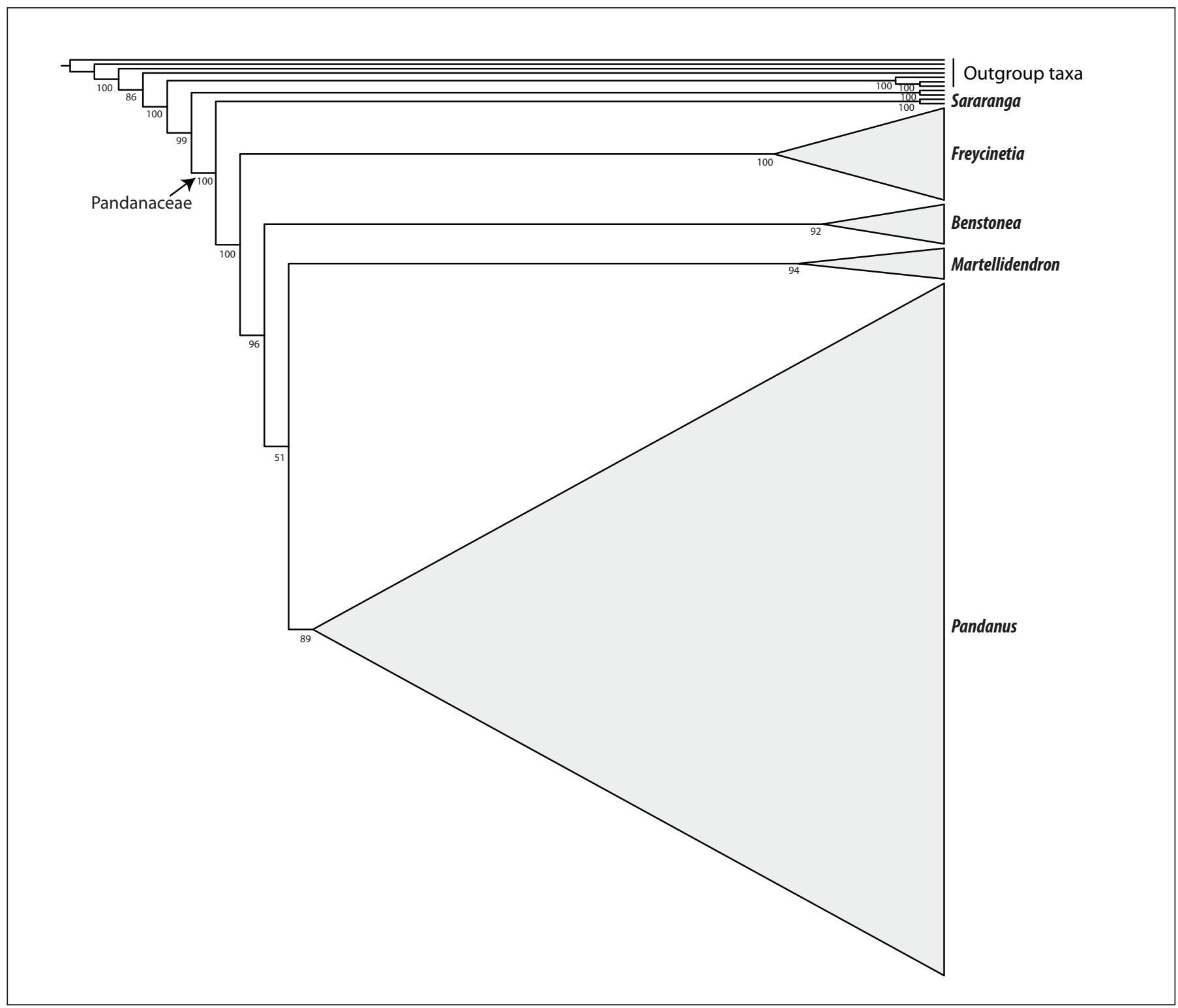

Fig. 2. - Plastid maximum likelihood phylogenetic tree of Pandanaceae inferred using RAxML and based on matK, trnL-trnF and trnQ-rps 16 . Bootstrap support values are represented below branches. This figure is adapted from the figure S1 in BUERKI \& al. (2012).

3. Drupes with endocarp not extending between the seed locules, but replaced by the mesocarp extending from the apex to the base; stigmas two, forming a cross at the apex of the pileus; staminodia present at the base of each drupe, each comprising a filament and an anther with four sterile pollen sacs Martellidendron

3a. Drupes with endocarp extending between the seed locules surrounded by mesocarp; stigma(s) 1 to numerous, of various shapes but never two and forming a cross at the apex of the pileus; staminodia rarely and abnormally present. ... 4
4. Carpels either free or connate into multicarpellate, severalseeded drupes; stigmas always on the adaxial side of the style, variable in shape but usually not sharp and linear (but if so with stigmas always on the abaxial side of the style); staminate flower with several connate stamens, i.e. borne on a stemonophore, rarely free (in P. epipythicus Martelli and P. pentodon Ridl.)

Pandanus

4a. Carpels always free, forming one-seeded drupes; stigmas always positioned on abaxial side of the style, sharp, linear; staminate flower reduced to one stamen, or in triads, free or very slightly joined at the base.

Benstonea 


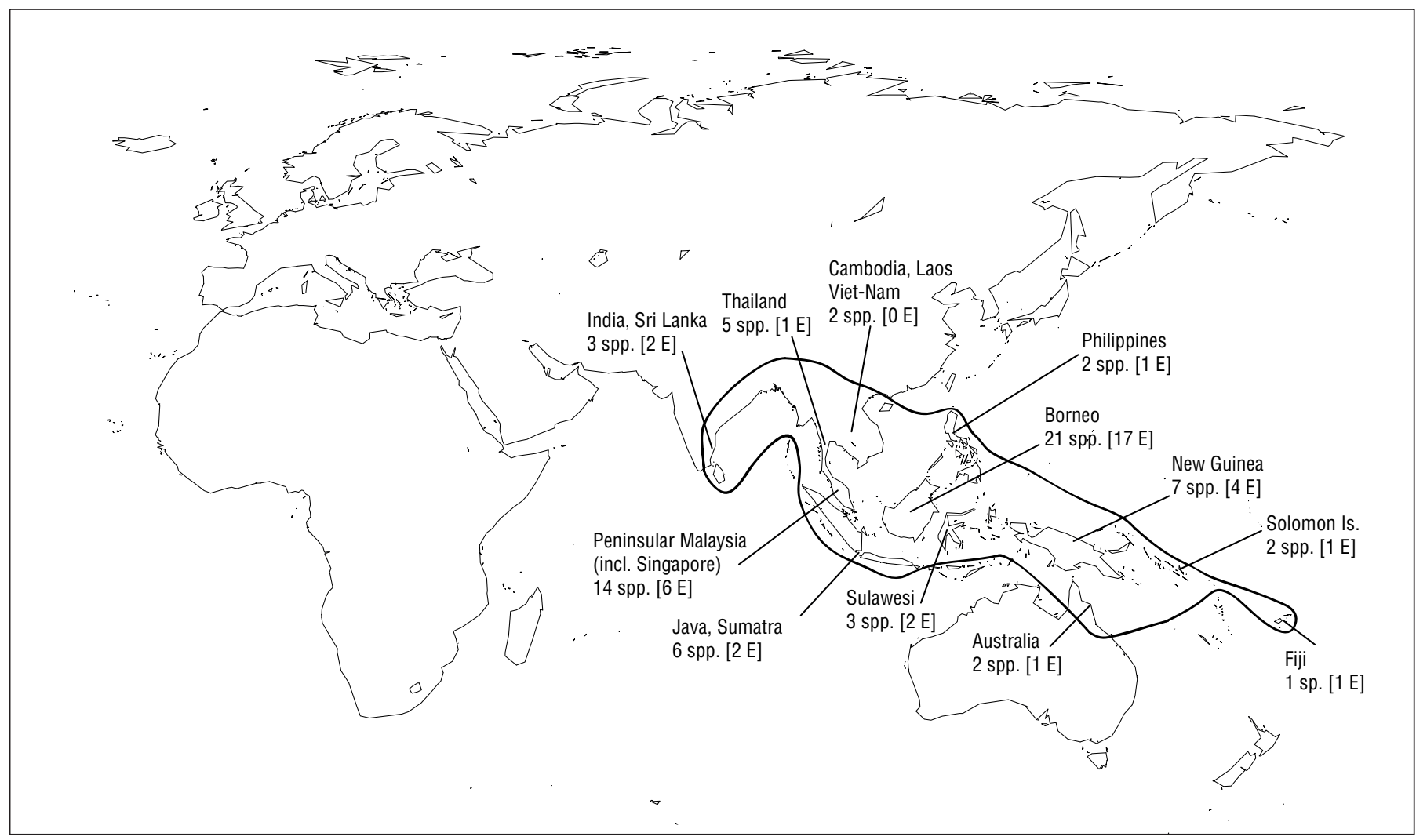

Fig. 3. - Distribution map of Benstonea Callm. \& Buerki showing the number of species and the level of endemicity per geographical region.

Benstonea Callm. \& Buerki, nom. \& stat. nov.

$\equiv$ Pandanus sect. Acrostigma Kurz in J. Bot. 5: 100. 1867. $\equiv$ Pandanus subg. Acrostigma (Kurz) B. C. Stone in Bot. Jahrb. Syst. 94: 521.1974 [non Acrostigma O. F. Cook \& Doyle (Arecaceae) in Contr. U.S. Natl. Herb. 16: 228. 1913].

Type: Benstonea affinis (Kurz) Callm. \& Buerki ( $\equiv$ Pandanus affinis Kurz) (lectotype designated by ST. JOHN 1960: 226).

Acaulescent or short-stemmed shrubs, often epiphytic, rarely tall trees. Leaves ligulate to linear-attenuate; leaf apex adaxially spinulose along the two main pleats (spines rarely absent). Inflorescences terminal or lateral on short side-branches, pistillate cephalia solitary, sometimes spicately disposed. Cephalia always of simple drupes, drupes never connate into phalanges; pileus usually distinct and calyptrate, grading upward into a hard, spiniform style; stigma linear, always positioned on abaxial side of the style. Endocarp usually with seed-chamber roofed by a thin cartilaginous partition above which is located a small more or less distinct supra-seminal chamber distinct from the rest of the apical mesocarp. Staminate inflorescence normally spicate. Staminate flowers sessile, composed of free stamens with anthers much longer than the short or nearly obsolete filaments, apiculate, sometimes stamens arranged in pauci-staminate dyads, phalanges or triads.

Etymology. - This genus is named in honour of Benjamin Clemens Stone (1933-1994) to whom we dedicate this article. Ben contributed immensely to the taxonomy of Pandanaceae and was the leading authority on the family for several decades; his work will remain fundamental to the study of the group for many years to come.

Observations. - As suggested above, our current understanding of relationships indicates that the entity recognized by StONe (1974) as Pandanus subg. Acrostigma is probably not monophyletic, and that the group treated here as Benstonea should be limited to include only the members historically assigned to Pandanus sect. Acrostigma (excluding P. microglottis), along with two clearly related species originally placed in sect. Fusiforma (P. pachyphyllus and P. biplicatus). The other species 
assigned to Pandanus subg. Acrostigma by StONe (1974), viz. the members of sects. Epiphytica and Pseudoacrostigma, along with the remaining species of sect. Fusiforma, are morphologically distinct and currently remain in Pandanus (as redefined here), although their taxonomic affinities within the family remain to be elucidated.

Benstonea is the third largest genus of Pandanaceae, with 50 currently accepted species (see below). It ranges from India to Australia with its centre of diversity in Borneo (21 spp. [17 of which are endemic]) and Peninsular Malaysia (14 spp. [6 endemic]), where two third of the species are found (Fig. 3). Most members of the genus are acaulescent or shortstemmed shrubs, or facultative or true epiphytes, rarely tall trees [e.g. B. atrocarpus (Griff.) Callm. \& Buerki]. Species occur in a variety of habitats including lowland rainforest, swamps, mangrove fringes and montane forests on various soil types (granitic, sandstone and limestone) (STONE, 1978). Benstonea can be easily recognized in the field by its: 1) staminate flowers bearing single (sometimes 2 or 3 connate) stamens with a short filament and a narrow anther; and 2) pistillate drupes always monocarpellate, with a sharp spiniform style and an abaxial stigmatic groove (Figs. 4-6). When fertile, the only taxa with which Benstonea can possibly be confused are some species of Pandanus sect. Solmsia B. C. Stone from subg. Rykia (de Vriese) B. C. Stone, which also bear simple spiniform styles, but which have a stigmatic groove that is always adaxial on the style. The presence of teeth along the two ventral pleats of the leaf apex can also help to recognize Benstonea when sterile, although some Pandanus species found in regions where Benstonea is present (i.e. Pandanus echinodermos Holttum \& H. St. John and P. pentodon Ridl., both occurring in Peninsular Malaysia) also bear ventral apical teeth (Stone, 1968a).

\section{A Synopsis of the genus Benstonea}

The following synopsis of the currently recognized species placed in Benstonea is based on observations of herbarium specimens deposited at key herbaria [Berlin (B), Berkeley (UC), Geneva (G), Firenze (FI), Harvard (A), Honolulu (BISH), Kew (K), Kuala-Lumpur (KLU), Leiden (L), Sabah (SAN), Sarawak (SAR), Saint-Louis (MO), Singapore (SING) and Washington (US)] and previous taxonomic revisions, supplemented with collections and observations made during fieldwork recently conducted in Fiji and Borneo (Sabah and Sarawak). A total of 50 species are provisionally accepted. Taxa in Peninsular Malaysia (BEEnTJE, unpubl. data), Indonesia (incl. Sulawesi, Sumatra, Papua and adjacent Islands; KeIM, 2009a, 2009b, 2012) and Thailand (MWC \& SB) are currently being revised, and as a consequence the number of species assigned to the genus will likely change in the coming years.
1. Benstonea adinobotrys (Merr. \& L. M. Perry) Callm. \& Buerki, comb. nova.

$\equiv$ Pandanus adinobotrys Merr. \& L. M. Perry in J. Arnold Arbor. 21: 175. 1940.

Typus: IndONESIA. Papua (New Guinea): $15 \mathrm{~km} \mathrm{SW}$ of Bernhard Camp, Idenburg River, I.1939, L. J. Brass 12077 (holo-: A [A00019999, A000120000] images seen; iso-: BRI).

= Pandanus congregatus H. St. John in Pacific Sci. 27: 44. 1973. Typus: Indonesia. Papua (New Guinea): Hunsteinspitze, 28.II.1913, Ledermann 11117 (holo-: B [B100 367676] image seen), syn. nov.

= Pandanus ketele B. C. Stone in J. Arnold Arbor. 64: 312. 1983. Typus: Papua New Guinea. Southern Island Prov.: Tary Valley, IX.1981, Stone \& Rose 15005 (holo-: PH [PH00018278, PH00018279, PH00018280] images seen; iso-: K [K000781425]!, PH [PH00018281, PH00019091 carpo.] images seen), syn. nov.

= Pandanus lustrorum B. C. Stone in J. Arnold Arbor. 64: 313. 1983. Typus: Papua New Guinea. West Sepik Prov:: Telefomin, III.1975, Womersley \& Waikabu NGF 48718 (holo-: KLU!; iso-: BRI, LAE [LAE222061] image seen), syn. nov.

Distribution and ecology. - Benstonea adinobotrys occurs from (400-)1400-2250 m in humid forest (JEBB, 1992). It is known in Indonesia (Sulawesi, West Papua) and Papua New Guinea.

Observations. - This taxon comprises a complex that includes several "morpho-species" that have been described based on slight variations in leaf length and width, and the dimensions and number of syncarps. As stated by STONE (1983c), the "limits of variation within members of this group are still not very well understood, and further field study of them is desirable". The taxonomic revision of Pandanaceae for the region currently being undertaken by Ary Keim and collaborators will hopefully clarify this matter. Some of the names placed in synonymy above may represent entities that justify recognition at the species level, in which case new combinations in Benstonea will be required. 
2. Benstonea affinis (Kurz) Callm. \& Buerki, comb. nova. $\equiv$ Pandanus affinis Kurz in J. Bot. 5: 101. 1867.

Typus: IndONESIA. Bangka Isl.: Kurz (lecto-: BO) (designated by STONE, 1978: 13).

$=$ Pandanus merrillii Warb. in Perkins, Fragm. Fl. Philipp. 1: 50. 1904. Typus: PhilipPines. Palawan Isl.: San Antognio Bay, II.1903, Merrill 840 (holo-: B [B100279959] image seen; iso-: FI [FI003946] image seen, NY, US [US00086602] image seen), syn. nov.

$=$ Pandanus sarawakensis Martelli in Bull. Soc. Bot. Ital. 1904: 303. 1904. Lectotypus (designated here): Malaysia. Sarawak (Borneo): Kuching, VIII.1865, Beccari 350 (FI-B [FI003947: Erbario Beccari 11902, carpo.]!), syn. nov.

Distribution and ecology. - Benstonea affinis is found in peat swamps and gallery forest/river edges from sea level to c. $500 \mathrm{~m}$. It is a widespread species, distributed from Peninsular Malaysia to the Philippines, including Vietnam, Sumatra, Singapore, and Borneo.

Observations. -This species is characterized by its 3 to 9 ovoid fruit heads crowded at the apex of an erect peduncle (Fig. 4A). Stone (1972, 1978, 1983a, 1993a), mentionning some differences in dimensions of the fruit, recognized the two species placed in synonymy above, albeit with doubt. He wrote: "Pandanus merrilli Warb. is so similar to P. affinis Kurz that, on the basis of herbarium material alone, discrimination is virtually impossible" (StONe, 1983a: 208). Pandanus sarawakensis was described by MARTELLI (1904) on the basis of two syntypes: Beccari 350 and 1895 . The first of these, misprinted as 550 in MARTELLI (1904: 303), is designated here as the lectotype because it comprises a sheet with a leaf and an infructescence deposited in the Beccari herbarium and a spirit collection of one syncarp in the associated carpological collection. Further taxonomic work is clearly needed for a better understanding of Benstonea affinis with respect to its relatives, especially B. ellipsoidea (Warb.) Callm. \& Buerki (see below).

3. Benstonea alticola (Holttum \& H. St. John) Callm. \& Buerki, comb. nova.

$\equiv$ Pandanus alticola Holttum \& H. St. John in Pacific Sci. 16: 218. 1962.

Typus: MalaYsia. Johore (Peninsular Malaysia): Sungei Kayu, Mawai-Jemaluang rd., II.1935, Corner s.n. (holo-: SING [SING0169801]!).

Distribution and ecology. - Benstonea alticola is found in montane forest and is an epiphyte growing to $12 \mathrm{~m}$ above ground, or a terrestrial shrub on limestone domes in Peninsular Malaysia (Bukit Takun, Selangor; Gua Musang, Kelantan) and Borneo (Sarawak) at an altitude of c. 700-1500 m.
Observations. - This facultative epiphytic shrub, with one large clump of leaves on a very short stem, has only a single terminal syncarp. A broader species concept, including other facultative epiphytes recognized here as distinct species such as B. inquilina (B. C. Stone) Callm. \& Buerki, may ultimately prove to be more appropriate, but further fieldwork will be required to determine the preferable circumscription of species.

4. Benstonea andersonii (H. St. John) Callm. \& Buerki, comb. nova.

$\equiv$ Pandanus andersonii H. St. John in Pacific Sci. 15: 576. 1961.

Typus: MalaYsia. Sarawak (Borneo): Lawas, XI.1960, Anderson s.n. (holo-: SAR!).

Distribution and ecology. - Benstonea andersonii is known from freshwater swamp forests of Borneo (Sabah and Sarawak) (Stone, 1993).

5. Benstonea ashtonii (B. C. Stone) Callm. \& Buerki, comb. nova.

$\equiv$ Pandanus ashtonii B. C. Stone in Fed. Mus. J. 23: 32. 1978.

Typus: BRUneI: Gunong Pagon Periok, IV.1958, P. S. Ashton 283 (holo-: K [K000781334]!; iso-: PH [PH960512] image seen).

Distribution and ecology. - Benstonea ashtonii is known from tropical forest understorey of North Borneo (Brunei and Sabah) (Stone, 1993).

6. Benstonea atrocarpa (Griff.) Callm. \& Buerki, comb. nova. $\equiv$ Pandanus atrocarpus Griff., Not. Pl. Asiat. 3: 160 . 1851.

Typus: Malaysia. Malacca: Griffith s.n. (holo-: K).

Distribution and ecology. - Benstonea atrocarpa occurs in lowland swamp forests in Peninsular Malaysia, Singapore and Sumatra (Stone, 1978).

7. Benstonea beccata (B. C. Stone) Callm. \& Buerki, comb. nova.

$\equiv$ Pandanus beccatus B. C. Stone in Sandakania 2: 65 . 1993.

Typus: Malaysia. Sarawak (Borneo): Mt. Kinabalu, Marai Parai ridge, 17.I.1983, Ansow, Kulip \& Tan SNP 1054 (holo-: SNP!).

Distribution and ecology. - Benstonea beccata is endemic to the montane forests around Mt. Kinabalu in Borneo (Sabah) (STONE, 1993). 

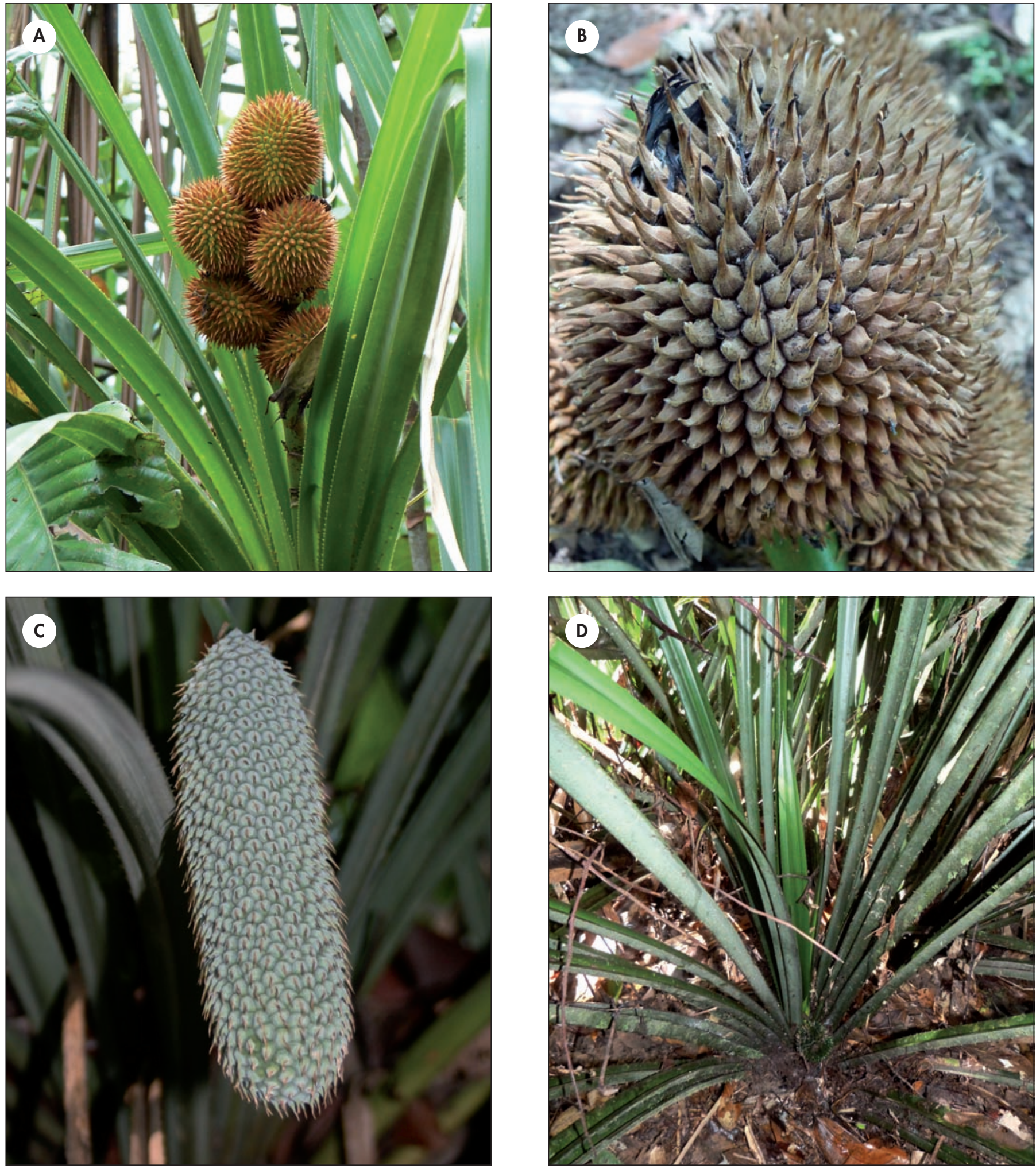

Fig. 4. - Infructescences and details of stigmas of species of Benstonea Callm. \& Buerki. A. Benstonea affinis (Kurz) Callm. \& Buerki; B. Benstonea gibbsiana (Martelli) Callm. \& Buerki; C. Benstonea ornata (Solms) Callm. \& Buerki; D. Benstonea pachyphylla (Merr.) Callm. \& Buerki.

[Photos: M. W. Callmander] 
8. Benstonea biplicata (H. St. John) Callm. \& Buerki, comb. nova.

$\equiv$ Pandanus biplicatus H. St. John in Pacific Sci. 17: 466. 1963.

Typus: ThaILAND. Jaujau: lower Siam, Kopah, 9.XII. 1917, Md. Haniff \& Md. Nur SFN 2703 (holo-: SING [SING0032172]!; iso-: K [K000781297]!).

Distribution and ecology. - Benstonea biplicata is restricted to southern Thailand, close to the Malaysian border (STONE, 1968b).

Observations. - This species was placed in Pandanus sect. Fusiforma by STONE (1968b), a section that we have not included in Benstonea (see above). Careful examination of the type in SING showed that its leaves $($ c. $4 \times 100 \mathrm{~cm}$ ) and styles (sharp and narrow) are similar to those in all the other species of Benstonea. Benstonea biplicata is therefore excluded from Pandanus sect. Fusiforma and transferred here to Benstonea. It is morphologically similar to B. nana (Martelli) Callm. \& Buerki, but differs in possessing a larger syncarp. Pending taxonomic revisions in the region should help clarify the status of this taxon.

9. Benstonea brevistylis (B. C. Stone) Callm. \& Buerki, comb. nova.

$\equiv$ Pandanus brevistylis B. C. Stone in Fed. Mus. J. 23: 39. 1978.

Typus: Malaysia. Sabah (Borneo): Beaufort Dist., Lumat, V.1961, J. Singh SAN 24235 (holo-: SAN!; iso-: K [K000781344]!).

Distribution and ecology. - Benstonea brevistylis is endemic to lowland tropical forest understorey in Borneo (eastern Sabah) (STONE, 1993).

10. Benstonea brunigii (B. C. Stone) Callm. \& Buerki, comb. nova.

$\equiv$ Pandanus brunigii B. C. Stone in Fed. Mus. J. 23: 32. 1978.

Typus: Malaysia. Sarawak (Borneo): Miri, Sg. Dalam Forest Reserve, 5.V.1959, E. F. Brunig $S 17492$ (holo-: SAR!).

Distribution and ecology. - Benstonea brunigii is endemic to lowland tropical forest understorey in Borneo (Sarawak) (StONe, 1993).
11. Benstonea calcinacta (B. C. Stone) Callm. \& Buerki, comb. nova.

$\equiv$ Pandanus calcinactus B. C. Stone in Fed. Mus. J. 23: 57. 1978.

Typus: MALAYSIA. Sarawak (Borneo): Baram Dist., Gunong Api, 12.VII.1961, Anderson 4720 (holo-: SAR!).

Distribution and ecology. - Benstonea calcinata (B. C. Stone) Callm. \& Buerki is endemic to limestone hills in Gunung Mulu National Park in Borneo (Sarawak) (STONE, 1993).

12. Benstonea celebica (Warb.) Callm. \& Buerki, comb. nova.

$\equiv$ Pandanus celebicus Warb. in Engl., Pflanzenr. 3(IV, 9): 80. 1900.

Typus: IndONESIA. Sulawesi: s.d., Warburg s.n. (holo-: B [B100279969] image seen; iso-: FI [FI003942] image seen).

Distribution and ecology. - Benstonea celebica is restricted to Sulawesi (Indonesia) (STONE, 1978).

Observations. - The delimitation of this taxon remains challenging. The fruiting material deposited at B was apparently destroyed, but a photograph is deposited at FI. According to WARBURG'S description (1900), B. celebica is morphologically very similar to $B$. pachyphylla (Merr.) Callm. \& Buerki. STONE (1978) has suggested that these two entities may be conspecific, but in the absence of fruiting material we have opted to maintain them as distinct until new collections are available.

13. Benstonea copelandii (Merr.) Callm. \& Buerki, comb. nova.

$\equiv$ Pandanus copelandii Merr. in Publ. Bur. Sci. Gov. Lab. 17: 7. 1904

Typus: PhiliPPines. Negros: Gimagong River, 5.I.1904, Copeland 140 (PNG destroyed; iso-: FI not located).

Neotypus (designated here): PHILIPPINEs. Sorsogon Prov. (Luzon): Mt. Bulusan, Irosin, IV.1916, fr., Elmer 15267 (G [G00353830]!; isoneo-: FI [FI003948] image seen, K, L, MO!, P [P01754716]!, U, UC [UC273333] image seen, US [US01115658] image seen).

$=$ Pandanus copelandii var. panchoi B. C. Stone in Fed. Mus. J. 23: 25. 1978. Typus: PhilipPines. Sorsogon Prov. (Luzon): Gubat, 25.X.1960, fr., Pancho \& Bardenas 4820 (holo-: CAHP), syn. nov.

Distribution and ecology. - Benstonea copelandii is endemic to the Philippines (ranging from Luzon to Mindanao). 
Observations. - The holotype, deposited at the herbarium in Manila (PNG), was destroyed during World War II, but a fragment has been located in FI. The original collection was rather incomplete, comprising only a few drupes, which were illustrated in MARTELLI (1914: Tab. 31, Fig. 57) and Sт. JoHN (1969: 357, Fig. 295). We have not been able to locate the duplicate material at FI despite an extensive search. A neotype (Elmer 15267) is therefore designated here. This collection is complete and well represented in several herbaria. Pandanus copelandii var. panchoi is considered as a synonym. It was described on the basis of a collection bearing only a single syncarp (vs 3-8 crowded, spicate syncarp in the remaining collections of Benstonea copelandii), but is considered to fall within the morphological variation of the species, even though it is rather atypical and is documented only by a single collection.

14. Benstonea ellipsoidea (Warb.) Callm. \& Buerki, comb. nova.

$\equiv$ Pandanus ellipsoideus Warb. in Engl., Pflanzenr. 3(IV, 9): 81.1900.

Typus: Indonesia. Sulawesi: Südlicher teil, s.d., Warburg 16151 (lecto-: B [B100279961] image seen) (designated by STONE, 1978: 15).

= Pandanus dipsaceus Martelli in Boll. Soc. Bot. Ital. 1904: 304. 1904. Typus: IndonESIA. Sulawesi : SE, Kandari, Lepo-Lepo, VII.1874, Beccari s.n. (holo-: FIB [FI003935: Erbario Beccari 11903, 11903A, 11903B, 11903C] images seen), syn. nov.

Distribution and ecology. - Benstonea ellipsoidea is confined to the mountain rainforests of the island of Sulawesi in Indonesia (STONE, 1978).

Observations. - This taxon was described on the basis of an immature infructescence (Warburg 16151), which is almost impossible to distinguish from Beccari s.n., type of Pandanus dipsaceus. In his revision, STONE (1978) maintained these two as separate species, albeit with much doubt. Benstonea ellipsoidea is indeed very similar to $B$. affinis, but it differs in the shape and dimensions of itsdrupes and the syncarps. Moreover, B. ellipsoidea is found at high altitude on limestone substrate in Sulawesi (KeIM, pers. comm.), whereas B. affinis is found in lowland peat swamp forests from Vietnam to Peninsular Malaysia, Borneo and Indonesia (Bangka, Sumatra). Given the strong ecological differences between these taxa, we tentatively follow the treatment of STONE (1978).
15. Benstonea elostigma (Martelli) Callm. \& Buerki, comb. nova.

$\equiv$ Pandanus elostigma Martelli in Boll. Soc. Bot. Ital. 1904: 303. 1904.

Typus: Malaysia. Perak (Peninsular Malaysia): Larut, IX.1884, King's Collector (Kunstler) 6559 (lecto-: CAL; isolecto-: SING [SING0059007]!) (designated by ST. JoHN, 1965: 224).

Distribution and ecology. - Benstonea elostigma occurs in lowland rainforests at c. 30-700 m in Peninsular Malaysia.

16. Benstonea foetida (Roxb.) Callm. \& Buerki, comb. nova. $\equiv$ Pandanus foetidus Roxb., Fl. Ind. ed. 1832, 3: 742. 1832.

$\equiv$ Pandanus wallichianus Martelli in Webbia 4:36. 1913 [nomen nudum].

Neotypus (designated here): BurMa: Amherst, 1827, Cat. Wallich 8588 (K [K000781275]!; isoneo-: K [K000781 276]!, M [M0175808, M0175809, M0175813] images seen).

Distribution and ecology. - Benstonea foetida is found in lowland and swamp forests around the Bay of Bengal in Bangladesh, Burma and India (STONE, 1978).

Observations. - ROXBURG described this species in 1832 in his Flora Indica. He wrote that it grew wild in Bengal and was cultivated at the Royal Botanic Gardens in Calcutta. A careful search of various herbaria known to hold collections made by Roxburg failed to reveal any authentic material of Benstonea foetida. In WALLICH's catalogue (1831), published the year before the protologue, two collections can be attributed to Pandanus foetidus: Wallich 8588 \& 8591 . The latter of these represents a staminate inflorescence (E [E00567756] image seen; FI image seen; K image seen; M [M0175810] image seen) from Sillet [Sylhet] in Bangladesh. The other collection, Wallich 8588 , consists of leaves and separate drupes from Amherst in Burma (WALLICH, 2005). This collection, held at $\mathrm{K}$ with some possible duplicates in $\mathrm{M}$, was cited under the nomen nudum, P. wallichianus (MARTELLI, 1913). The K specimen is here designated as the neotype.

17. Benstonea gibbsiana (Martelli) Callm. \& Buerki, comb. nova.

$\equiv$ Pandanus gibbsianus Martelli in J. Linn. Soc., Bot. 42: 170. 1914

Typus: Malaysia. Sabah (Borneo): between Tambunan and Korikut, II.1930, S. L. Gibbs 3030 (holo-: BM [BM00 0958510]!).

Distribution and ecology. - Benstonea gibbsiana is known only from lowland rainforests $(>800 \mathrm{~m}$ ) in Sabah (Borneo) (Fig. 4B). 

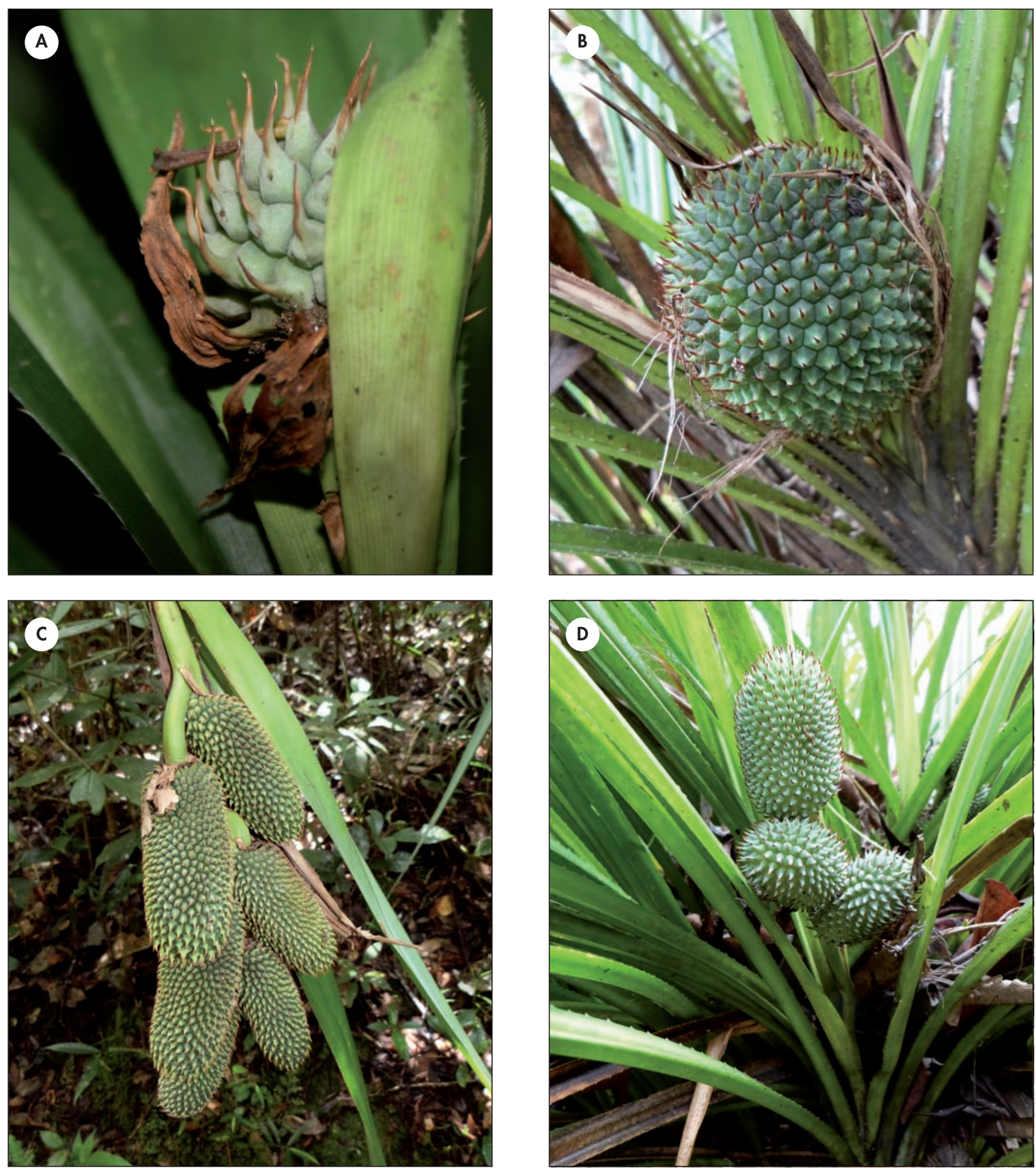

Fig. 5. - Infructescences and details of stigmas of species of Benstonea Callm. \& Buerki. A. Benstonea parva (Ridl.) Callm. \& Buerki; B. Benstonea pectinata (Martelli) Callm. \& Buerki ; C. Benstonea rupestris (B. C. Stone) Callm. \& Buerki; D. Benstonea thomissophylla (B. C. Stone) Callm. \& Buerki.

[Photos: M. W. Callmander] 
18. Benstonea glaucophylla (Ridl.) Callm. \& Buerki, comb. nova.

$\equiv$ Pandanus glaucophyllus Ridl. in J. Straits Branch Roy. Asiat. Soc. 41: 50. 1904.

Typus: Malaysia. Perak (Peninsular Malaysia): Thaiping Hill, XII.1898, Ridley s.n. (holo-: SING [SING005 9042]!).

Distribution and ecology. - Benstonea glaucophylla appears to be restricted to lowland rainforests $(450-750 \mathrm{~m})$ of Peninsular Malaysia (STONE, 1978).

19. Benstonea herbacea (Martelli) Callm. \& Buerki, comb. nova.

$\equiv$ Pandanus herbaceus Martelli in Boll. Soc. Bot. Ital. 1904: 303. 1904.

Lectotypus (designated here): Malaysia. Perak (Peninsular Malaysia): Trang, III.1881, Kunstler 1397 (FI [FI003936] image seen).

Distribution and ecology. - Benstonea herbacea grows in lowland and mountain rainforests $(600-1300 \mathrm{~m})$ of northern Peninsular Malaysia and the southern part of Thailand (STONE, 1978).

Observations. - The collection locality for the type of Pandanus herbaceus Martelli was cited as "Irang, Penins. Malese (H. Calc.)" (Martelli, 1904: 303). Stone (1978: 37) later indicated "coll. ignot.", but a fragment in Martelli's herbarium (FI) clearly comes from the type locality cited by Martelli and was collected by H. H. Kunstler (Kunstler 1397), and should be considered as type material. Because the holotype in CAL was not located by B. C. Stone and appears to have been lost, the collection in FI is here designated as the lectotype.

20. Benstonea humilis (Lour.) Callm. \& Buerki, comb. nova.

$\equiv$ Pandanus humilis Lour., Fl. Cochinch.: 603. 1790.

Typus: VieTnAM. Tourane [Danang]: Annam, 22.VIII. 1927, J. \& M. S. Clemens 4173 (neo-: P [P02085855]!; isoneo-: $\mathrm{B}, \mathrm{G}$ [G00355114]!, UC) (designated by STONE, 1978: 17).

Distribution and ecology. - Benstonea humilis grows in rainforests from NE India to Peninsular Malaysia from sea level to c. $300 \mathrm{~m}$ (STONE, 1983b).

Observations. - Benstonea humilis, as circumscribed here, includes the types of many validly published names. A complete synonymy can be found in Appendix 1 .
21. Benstonea inquilina (B. C. Stone) Callm. \& Buerki, comb. nova.

$\equiv$ Pandanus inquilinus B. C. Stone in Fed. Mus. J. 23: 60. 1978

Typus: MalaYsia. Sabah (Borneo): Sandakan Dist., Ulu Dusun, 28.III.1977, Stone \& al. 12890 (holo-: KLU!; iso-: K!, PH [PH00018271, PH0001 8272] image seen, SAN!).

Distribution and ecology. - Benstonea inquilina is only known by the type specimen, collected near Sandakan in lowland secondary rainforests.

22. Benstonea korthalsii (Solms) Callm. \& Buerki, comb. nova.

$\equiv$ Pandanus korthalsii Solms in Linnaea 42: 12. 1878.

Typus: INDONESIA. Kalimatan (Borneo): s.d., Korthals s.n. (holo-: L [L0050555] image seen; iso-: B [B1002 79935, B180002796, carpo.] images seen, L [L0050556, L0050557] images seen).

Distribution and ecology. - Benstonea korthalsii occurs in rainforests from Borneo to Sumatra (STONE, 1978).

23. Benstonea kurzii (Merr.) Callm. \& Buerki, comb. nova. $\equiv$ Pandanus kurzii Merr., Interpr. Herb. Amboin.: 107. 1917.

Typus: IndonesIA. Java: Mt. Salak, 17.V.1863, Coll. ignot. (lecto-: BO) (designated by Stone, 1972: 29).

Distribution and ecology. - Benstonea kurzii is confined to the rainforests of Java (Indonesia) (STONE, 1978).

24. Benstonea lauterbachii (K. Schum. \& Warb.) Callm. \& Buerki, comb. nova.

$\equiv$ Pandanus lauterbachii K. Schum. \& Warb. in Engl., Pflanzenr. 3(IV, 9): 81. 1900.

Typus: Papua New Guinea. Madang Prov.: Gogol, 28.X.1890, Lauterbach 863 (holo-: B [B100216880] image seen).

Distribution and ecology. - Benstonea lauterbachii grows on wet soils, in swamps or near mangroves in New Guinea (West Papua, Papua and Papua New Guinea) and in northern Australia (Queensland) (WILSON, 2011). 
25. Benstonea lepatophila (B. C. Stone) Callm. \& Buerki, comb. nova.

$\equiv$ Pandanus lepatophilus B. C. Stone in Bot. J. Linn. Soc. 85: 31. 1982.

Typus: Malaysia. Sarawak (Borneo): Gunung Mulu NP, 14.IV.1978, Argent \& Jermy 973 (holo-: E [E0031 8031] image seen; iso-: KLU!, SAR!).

Distribution and ecology. - Benstonea lepatophila is endemic to the limestone hills of Gunung Mulu National Park in Borneo (Sarawak) (STONE, 1993).

26. Benstonea monticola (F. Muell.) Callm. \& Buerki, comb. nova.

= Pandanus monticola F. Muell., Fragm. 5: 40. 1865.

Typus: Australia. Queensland: around Rockingham Bay, 1864, Dallachy s.n. (holo-: MEL; iso-: P [P02138 396, P02138397]!).

Distribution and ecology. - Benstonea monticola is restricted to the lowland rainforests (from sea level to $800 \mathrm{~m}$ ) in northeastern Australia (Queensland) (WILSON, 2011).

27. Benstonea nana (Martelli) Callm. \& Buerki, comb. nova. $\equiv$ Pandanus nanus Martelli in Webbia 1: 370. 1905.

Typus: Malaysia. Perak (Peninsular Malaysia): Larut, IV.1883, Kunstler 4080 (holo-: FI [FI003936: 3 sheets] images seen; iso-: SING [SING0059057]!).

Distribution and ecology. - Benstonea nana is endemic to the lowland rainforests of Peninsular Malaysia (Perak and Pahang) and southern Thailand occurring at an altitude of 90$300 \mathrm{~m}$ (STONE, 1978).

28. Benstonea odoardii (Martelli) Callm. \& Buerki, comb. nova.

$\equiv$ Pandanus odoardii Martelli in Boll. Soc. Bot. Ital. 1904: 304. 1904.

Typus: Papua New Guinea. Western Prov.: Fly river, 1877, D'Albertis s.n. (holo-: FI-B [FI003939: Erbario Beccari 1526, 1526A, 1526B] images seen; iso-: FI [FI00 3940] image seen).

= Pandanus ihuanus Martelli in J. Arnold Arbor. 10: 141. 1929. Typus: Papua New Guinea. Central Prov.: Vailala River, 14.II.1926, Brass 978 (holo-: A [A0002 0041] image seen), syn. nov.

= Pandanus rostellatus Merr. \& L. M. Perry in J. Arnold Arbor. 20: 182. 1939. Typus: Papua New Guinea. Central Prov.: Kubuna, 15.XII.1933, Brass 5675 (holo-: NY [NY00311360] image seen; iso-: A [A0002 0069] image seen), syn. nov.
$=$ Pandanus humicola Kaneh. in Bot. Mag. (Tokyo) 55: 305. 1940. Typus: Papua New Guinea: rd. side to the Lake Angi, 5.IV.1940, Kanehira \& Hatusima 13500 (holo-: FU; iso-: A [A00020040] image seen), syn. nov.

$=$ Pandanus eumekes B. C. Stone in Fed. Mus. J. 23: 43. 1978. Typus: IndONESIA. West Papua (New Guinea): Sorong Dist., S of Radio Sorong, 7.IV.1954, P. Royen (holo-: L [L0050509] image seen), syn. nov.

Distribution and ecology. - Benstonea odoardii, as currently circumscribed, is widely distributed in lowland and montane rainforests of New Guinea (from 100 to 2000 m) (JeBB, 1982).

Observations. - The type collection of B. odoardii (D'Albertis s.n.), deposited in the Beccari herbarium (Erbario Beccari della Malesia) in FI, includes the holotype mounted on three sheets, two with leaves and one with the infructescence. Another possible fragment of the infructescence, considered here as an isotype, is also kept in Martelli's herbarium. This species is a stemless shrub with long slender leaves (up to 250 $\mathrm{cm}$ ) and a solitary sub-globose syncarp (c. $6-12 \mathrm{~cm}$ in diam.) borne on an erect peduncle (up to $60 \mathrm{~cm}$ ) (JEBB, 1992). The range of variation of $B$. odoardii accepted here follows JEBB (1982), who gathered several specimens that cannot be distinguished from other material of this species, even though the styles have a rather variable morphology: either short and acute or more slender to recurved. All this material seem to fall within the currently accepted range of variability of the species (JeBB, 1982). Further collections and fieldwork are required to determine whether this circumscription is appropriate or whether it may include more than a single variable species (JEBB, 1982).

29. Benstonea ornata (Solms) Callm. \& Buerki, comb. nova. $\equiv$ Pandanus ornatus Solms in Linnaea 42: 11. 1878 .

Lectotypus (designated here): MALAYSIA. Malacca: 1837, Gaudichaud 108 (G [G00164258]!; isolecto-: B [B1002 79958] image seen, P [P01751483, P01751484, P0175 1486, P01751487]!).

$=$ Pandanus monotheca Martelli in Boll. Soc. Bot. Ital. 1904: 303. 1904. Lectotypus (designated here): MALAYSIA. Malacca: Gunong Tundok, 1891, Ridley 10821 (FI [FI00 3937] image seen; isolecto-: G [G00353796]!; SING [SING0059013]!), syn. nov.

Distribution and ecology. - Benstonea ornata is distributed from Peninsular Malaysia to Borneo (through Sumatra and Singapore) and Thailand. It grows in forest understory on hilltops, often on poor soils, at an altitude of 300 to $1350 \mathrm{~m}$ (STONE, 1978). 
Observations. - Pandanus ornatus was first illustrated by GAUDICHAUD (1841) in the invalidely published genus Fisquetia Gaudich. This name was then invalidly transferred by KURZ (1869) to Pandanus, without a description. Solms-LAUBACH (1878), while attempting to transfer it to Pandanus, in fact described it as new, designating two syntypes: Gaudichaud's drawing and a Gaudichaud collection in the Delessert herbarium in $\mathrm{G}$ (Gaudichaud 108). His description thus validates the name as $P$. ornatus, even though he believed he was simply making a new combination. Gaudichaud 108 has both an infructescence and leaves, and is here designated as the lectotype. Benstonea ornata is characterized by a sub-cylindric cephalia (varying in length from 5 to $23 \mathrm{~cm}$ ), pendent on a long peduncle (up to $50 \mathrm{~cm}$ ) with sharp, proximally arcuate styles up to $5 \mathrm{~mm}$ in length (Fig. 4C). This species is wonderfully illustrated in Gaudichaud (1841: Tab. 5, Figs. 1, 8-9).

MarTelLi (1904) described Pandanus monotheca based on Ridley 10821. The holotype deposited at CAL was not found by Stone, neither in 1968 nor in 1974 (STONE, 1978), and this entity was therefore regarded by him as a poorly known species. Drupes of this collection (with neither leaves nor syncarps) were, however, subsequently found in both FI and G. The FI collection, here designated as lectotype, clearly belongs to Benstonea ornata, and Pandanus monotheca is therefore treated as a synonym.

30. Benstonea pachyphylla (Merr.) Callm. \& Buerki, comb. nova.

$\equiv$ Pandanus pachyphyllus Merr. in J. Straits Branch Roy. Asiat. Soc. 85: 154. 1922.

Lectotypus (designated here): Malaysia. Sabah (Borneo): Sandakan and vincity, IX-X.1920, fr., Ramos 1541 (US [US00086615] image seen; isolecto-: K [K00078 1368, K000781386]!, P [P02138353]!).

Distribution and ecology. - Benstonea pachyphylla is endemic to the lowland rainforests of Borneo (Kalimatan, Sabah and Sarawak).

Observations. - This species is very characteristic, with its acaulescent habit and syncarp borne in the middle of a large clump of leaves growing directly from the ground (Fig. 4D). Its leaves are similar to those of the poorly known B. celebica, the latter only known by its leaves and a picture of the fruit (see above). These may represent a single species that occurs in both Sulawesi and Borneo.
31. Benstonea parva (Ridl.) Callm. \& Buerki, comb. nova. $\equiv$ Pandanus parvus Ridl. in J. Straits Branch Roy. Asiat. Soc. 33: 171. 1900.

Typus: Singapore. Pulau Ubin: Kranji, 1892, Ridley 8928 (lecto-: SING [SING0059862]!) (designated by ST. JoHN, 1963: 337).

Distribution and ecology. - Benstonea parva grows in lowland to montane rainforests (from sea level to $1500 \mathrm{~m}$ ) and is distributed from Peninsular Malaysia through Singapore to Borneo (Sabah).

Observations. - This small terrestrial herbaceous species is characterized by its short monocaulous habit (up to $60 \mathrm{~cm}$ high), its broad but small leaves that are abruptly caudateacuminate in the distal part, glaucous on the abaxial surface, and its rather small globose terminal syncarp (Fig. 5A). It remains difficult to differentiate $B$. parva from $B$. unguiculata (Ridl.) Callm. \& Buerki (with slightly narrower leaves and larger fruit), and further collections are needed to confirm whether they are distinct.

32. Benstonea pectinata (Martelli) Callm. \& Buerki, comb. nova.

$\equiv$ Pandanus pectinatus Martelli in Boll. Soc. Bot. Ital. 1904: 304. 1904.

Typus: MaLaYSIA. Sarawak (Borneo): Beccari s.n. (holo-: FI [FI003941, carpo.] image seen).

Distribution and ecology. - Benstonea pectinata occurs in the montane rainforests (900-2500 m) of Borneo and has been collected twice in Sumatra (STONE, 1975a, 1978).

Observations. - This species is strictly epiphytic and easily distinguished from other epiphytic members of the genus (e.g. B. alticola) by its lobed auricles at the base of the leaves. Benstonea pectinata has often been collected on fallen trees in montane rainforests, but seems to be a strict epiphyte (Fig. 5B).

33. Benstonea permicron (Kaneh.) Callm. \& Buerki, comb. nova.

$\equiv$ Pandanus permicron Kaneh. in Bot. Mag. (Tokyo) 55: 258. 1940.

Typus: Indonesia. West Papua (New Guinea): Dallmann, Nabire, 2.III.1940, Inokuma 603 (holo-: FU; isoA [A00020067] image seen).

Distribution and ecology. - Benstonea permicron is found growing on clay between 100 to $1200 \mathrm{~m}$ in the rainforests of West Papua (New Guinea) (KANehiRA, 1940; Stone, 1982a). 
34. Benstonea pilaris (Ridl.) Callm. \& Buerki, comb. nova. $\equiv$ Pandanus pilaris Ridl. in J. Straits Branch Roy. Asiat. Soc. 86: 311. 1922.

Lectotypus (designated here): MALAYSIA. Negeri Sembilan (Peninsular Malaysia): Bukit Tangga, 10.XII.1920, Ridley s.n. (K [K00781286]!).

Epitypus (designated here): MaLaYsIa. Selangor (Peninsular Malaysia): Pantai Valley, 13.IX.1967, Mahmud \& Sharif s.n. (KLU image seen).

Distribution and ecology. - Benstonea pilaris is endemic to the rainforests of Peninsular Malaysia (STONE, 1969).

Observations. - The type collection (Ridley s.n.) has not been found in SING, but a steril duplicate has recently been rediscovered by $\mathrm{HB}$ at Kew, which is here designated as the lectotype. In 1978, STONE designated a specimen at KLU (Mahmud \& Sharif s.n.) as the neotype, but the rediscovery of the type revokes this nomenclatural act. As Mahmud \& Sharif s.n. is a fertile collection including a complete syncarp, and clearly belongs to $B$. pilaris, we designate it as the epitype.

35. Benstonea poronavila (B. C. Stone) Callm. \& Buerki, comb. nova.

$\equiv$ Pandanus poronavila B. C. Stone in Micronesica, Suppl. 1:1. 1966.

Typus: Solomon IsLands. Santa Isabel Isl.: Totolu islet, X.1957, Stone 2468 (holo-: BISH!; iso-: K [K0007 81510, K000781511]!).

Distribution and ecology. - Benstonea poronavila is confined to the Solomon Islands (in Santa Ysabel and Guadalcanal).

Observations. - The habit of Benstonea poronavila is very similar to that of B. setistyla (Warb.) Callm. \& Buerki, which occurs in Papua New Guinea, a poorly-known species represented by only a few collections from lowland forests in Sepik and Morobe Prov. (JeBB, 1992). The very long styles seem to be distinctive to B. setistyla (JEBB, 1992: 24), and we therefore maintain these two species separate. Further fieldwork will be needed to clarify whether they are indeed distinct.

36. Benstonea pseudosyncarpa (Kaneh.) Callm. \& Buerki, comb. nova.

$\equiv$ Pandanus pseudosyncarpus Kaneh. in Bot. Mag. (Tokyo) 54: 258. 1940.

Typus: Indonesia. West Papua (New Guinea): Nabire, 16.IV.1939, Inokuma 636 (holo-: FU).

Distribution and ecology. - Benstonea pseudosyncarpa occurs in lowland tropical rainforests (from c. 100 to $400 \mathrm{~m}$ ) (JeBB, 1992; KeIM, 2009, 2012) in Indonesian New Guinea (in Papua and recently found in the island of Yapen; KeIM, 2009).
37. Benstonea pumila (H. St. John) Callm. \& Buerki, comb. nova.

$\equiv$ Pandanus pumilus H. St. John in Pacific Sci. 19: 96. 1965.

Typus: Malaysia. Sarawak (Borneo): Gunung Pueh, 25.IX.1955, Purseglove 4799 (holo-: SING [SING005 9062]!).

Distribution and ecology. - Benstonea pumila is endemic to lowland rainforests of Sabah and Sarawak (Borneo).

38. Benstonea rupestris (B. C. Stone) Callm. \& Buerki, comb. nova.

$\equiv$ Pandanus rupestris B. C. Stone in Fed. Mus. J. 14: 129. 1972.

Typus: Malaysia. Sarawak (Borneo): Bukit Pantu, Melinau, Kapit, 9.VIII.1967, llias Paie 25728 (holo-: SAR!).

$=$ Pandanus oresbios B. C. Stone in Fed. Mus. J. 23: 58. 1978. Typus: IndonESIA. Kalimatan (Borneo): Central E, near Mt. Kemul, 12.X.1925, Endert 3896 (holo-: L [L0050606] image seen; iso-: A [A00019993] image seen), syn. nov.

$=$ Pandanus scandens B. C. Stone in Fed. Mus. J. 23: 59. 1978. Typus: MalaYsia. Sarawak (Borneo): Bintulu, Merurong Plateau, 16.IV.1960, Brunig 29924 (holo-: SAR!), syn. nov.

Distribution and ecology. - Benstonea rupestris is endemic to the lowland rainforests of Sabah and Sarawak (Borneo).

Observations. - Stone (1978) described Pandanus scandens based on a more mature infructescence than that of $P$. rupestris, which was described six years earlier. He distinguished these two taxa based on the number of syncarps (5 in P. scandens vs 7 to 9 in P. rupestris) and other minor morphological characters such as the leaf length (c. $3 \times 105 \mathrm{~cm}$ vs $3-4 \times 190 \mathrm{~cm}$ ) and color (glaucous vs not glaucous beneath). Recent observations in the field by MWC and SB have, however, confirmed that populations corresponding to Benstonea rupestris are characterized by a long pendent infructescence with up to 9 oblong syncarps (sometimes 5 to 8 ) and that leaf length and width fall within the normal variation of $B$. rupestris as currently circumscribed (Fig. 5C).

Pandanus oresbios, also described in 1978, is here considered as a synonym of Benstonea rupestris. It was described based on an immature infructescence, and despite its apparent narrower leaves ( $2 \mathrm{~cm}$ vs $3-4 \mathrm{~cm}$ in $B$. rupestris) and smaller syncarps (c. $3.5 \mathrm{~cm}$ in length vs $8 \mathrm{~cm}$ ), it appears to represent the same entity as $B$. rupestris. Further field observations are needed to understand the relationship between $B$. rupestris and $B$. calcinacta, another species that may also be part of this group but is provisionally accepted here (see above). 
39. Benstonea rustica (B. C. Stone) Callm. \& Buerki, comb. nova.

$\equiv$ Pandanus rusticus B. C. Stone in Fed. Mus. J. 14: 131. 1972.

Typus: MALAYSIA. Sarawak (Borneo): Kalabit highlands, Bario, 15.IV.1970, Nooteboom \& Chai 2108 (holo-: L [L00 50638] image seen; iso-: SAR!).

Distribution and ecology. - Benstonea rustica is endemic to the lowland rainforests of Sabah and Sarawak (Borneo).

40. Benstonea setistyla (Warb.) Callm. \& Buerki, comb. nova.

$\equiv$ Pandanus setistylus Warb. in Engl., Pflanzenr. 3(IV, 9): 81. 1900.

Typus: Papua New Guinea. Morobe Prov.: Finschhafen, s.d., Hollrung 175 (lecto-: B [B100460002] image seen; isolecto-: B [B100460001] image seen) (designated by STONE, 1978: 22).

Distribution and ecology. - Benstonea setistyla is restricted to lowland rainforests in Papua New Guinea (JeBB, 1982).

41. Benstonea stenocarpa (Solms) Callm. \& Buerki, comb. nova.

$\equiv$ Pandanus stenocarpus Solms in Ann. Jard. Bot. Buitenzorg 3: 91. 1883.

Typus: Indonesia. West Papua (New Guinea): Mts. Arfak, ad Hatam, VI.1875, Beccari s.n. (holo-: FI-B [FI003 937: Erbario Beccari 11486]!; iso-: B [B100279929] image seen).

$=$ Pandanus acicularis H. St. John in Pacific Sci. 27: 44. 1973. Typus: Papua New Guinea. Morobe Dist.: Sattelberg, 30.VII.1938, M. S. Clemens 8578 (holo-: B [B100279966] image seen), syn. nov.

$=$ Pandanus misimaensis B. C. Stone in Fed. Mus. J. 23: 54. 1978. Typus: Papua New Guinea: Misima Island, Mt. Sisa, 19.VII.1956, Brass 27401 (holo-: L [L0050582] image seen), syn. nov.

$=$ Pandanus gladiator B. C. Stone in Gard. Bull. Singapore 36: 209. 1984. Typus: IndONESIA. Sulawesi: Mt Roroka Timbu, c. $80 \mathrm{~km}$ SSE of Palu, 11.V.1979, Vogel 5287 (holo-: BO; iso-: L [L0332713] image seen, KLU!), syn. nov.

Distribution and ecology. - Benstonea stenocarpa grows in lowland to submontane rainforests (from sea level up to $1300 \mathrm{~m}$ ). It is distributed from the Moluccas through New Guinea and Bismarck archipelago to the Solomon Islands (KeIM, 2012).
Observations. - This species has recently been reviewed by KeIM (2012), who adopted a broad species concept, including as synonyms several entities spanning from the Mollucas (Halmahera Isl.) through the Bismark Archipelago to the northern part of the Solomon Island (Bougainville) (see KeIM, 2012 and Appendix 1). Among those synonyms, Pandanus misimaensis was regarded as a nomen nudum by KeIM (2012), but in fact the name was validly published by STONE (1978: 54). Another species, $P$. gladiator B. C. Stone, not mentioned in Keim's taxonomic review, shares all the morphological characters of $P$. stenocarpus, including its typical beaked styles (see Stone, 1983a: 210, Fig. 4), and is therefore considered as a synonym.

42. Benstonea sylvatica (B. C. Stone) Callm. \& Buerki, comb. nova.

$\equiv$ Pandanus sylvaticus B. C. Stone in Fed. Mus. J. 23: 31. 1978.

Typus: Malaysia. Sarawak (Borneo): Semengoh, 30. VIII.1977, Stone 13475 (holo-: KLU image seen; iso-: PH [PH00018604, PH00018605] images seen).

Distribution and ecology. - Benstonea sylvatica is endemic to lowland rainforests of Sarawak (Borneo).

43. Benstonea thomissophylla (B. C. Stone) Callm. \& Buerki, comb. nova.

$\equiv$ Pandanus thomissophyllus B. C. Stone in Fed. Mus. J. 14: 133.1972.

Typus: Malaysia. Sarawak (Borneo): Bau Dist., Bukit Jebong, 10.VII.1970, Anderson \& Chai S29924 (holo-: KLU image seen; iso-: SAR!).

Distribution and ecology. - Benstonea thomissophylla is endemic to limestone hills of the Sarawak state in Borneo.

Observations. - This species is morphologically very close to B. alticola, both of which grow in the Bau limestones in the north of Kuching (Sarawak, Borneo). Benstonea thomissopylla differs, however, from $B$. alticola by its spicate infrutescence ( 3 vs 1 in B. alticola) and larger leaves (c. $2.5 \times 300 \mathrm{~cm}$ vs $1.5 \times 140 \mathrm{~cm})($ Fig. $5 \mathrm{D})$. Further collections are needed to determine if these very closely related entities are conspecific. 


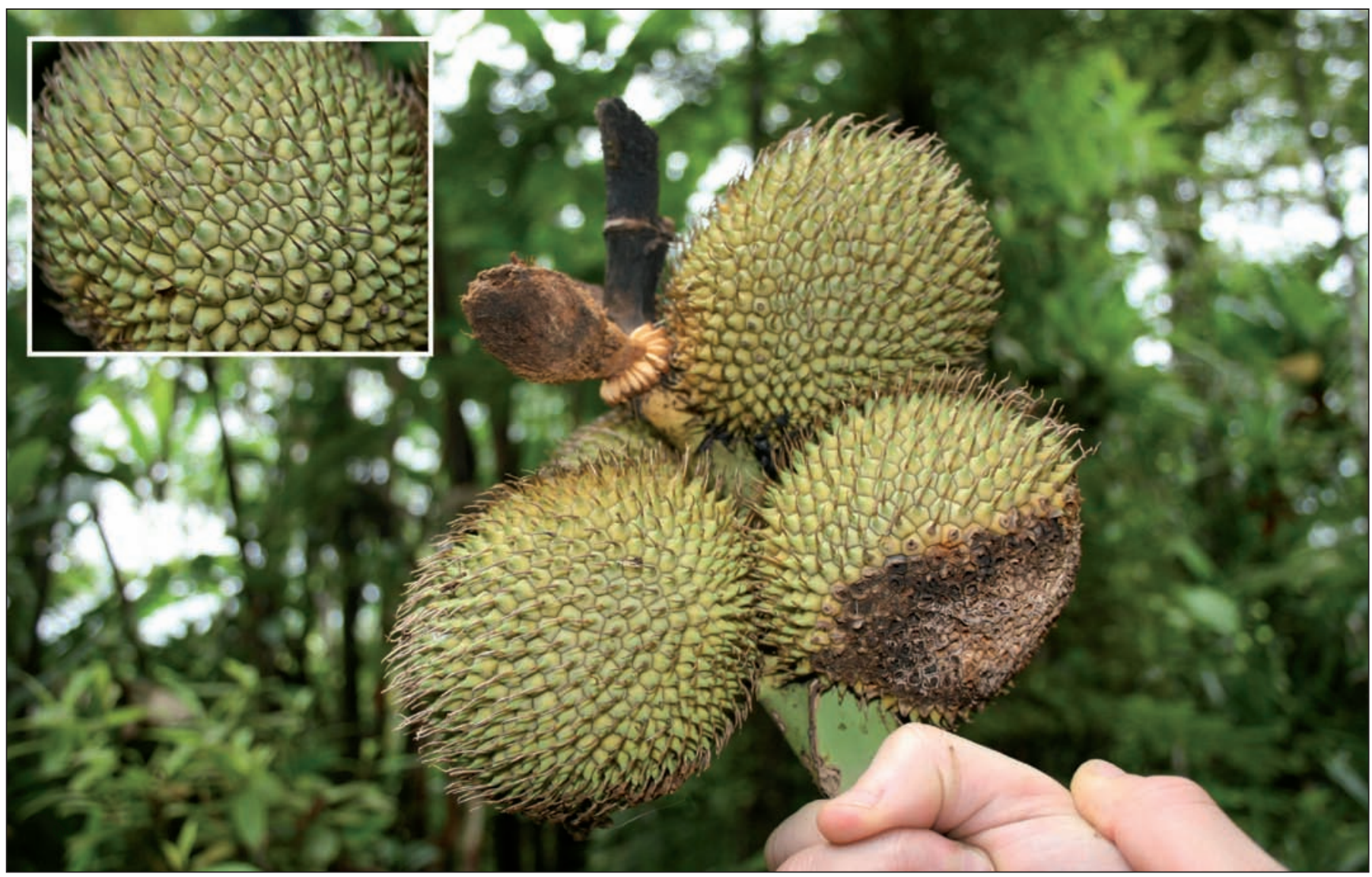

Fig. 6. - Infructescence of Benstonea thurstonii (C. H. Wright) Callm. \& Buerki with details of stigmas in frame.

[Photo: M. W. Callmander]

44. Benstonea thurstonii (C. H. Wright) Callm. \& Buerki, comb. nova.

$\equiv$ Pandanus thurstonii C. H. Wright in Bull. Misc. Inform. Kew 1894: 348. 1894.

Typus: FIJ. Viti Levu: V.1894, J. B. Thurston s.n. (holo-: K!; iso-: FI [FI003945]!).

Distribution and ecology. - Benstonea thurstonii is endemic to Fiji and has been recorded on the islands of Viti Lev and Koro, and has recently been collected on Vanua Levu (Fig. 6).

45. Benstonea thwaitesii (Martelli) Callm. \& Buerki, comb. nova.

$\equiv$ Pandanus thwaitesii Martelli in Webbia 1:369. 1905.

Typus: SRI LanKa. Central Prov.: 1863, Thwaites CP 3740 (lecto-: PDA; isolecto-: B [B100279917] image seen, G [G00164376, G00164377, G0357544]!, GH, K [K000781 270, K000781271]!; P [P02131269]!) (designated by STONE, 1975b: 121).

Distribution and ecology. - Benstonea thwaitesii is endemic to the lowland rainforests of Sri Lanka (STONE, 1975b).
46. Benstonea toei (H. St. John) Callm. \& Buerki, comb. nova.

$\equiv$ Pandanus toei H. St. John in Pacific Sci. 17: 468. 1963.

Typus: ThaILAnd: Krabi, $83 \mathrm{~km}$ from Huay Yawt, 28.I. 1958, Tem Smitinand 4143 (holo-: BKF [SN080179] image seen).

Distribution and ecology. - Benstonea toei is endemic to lowland evergreen forests in Thailand and Peninsular Malaysia.

Observations. - This species is morphologically similar to $B$. humilis but lacks the tesselate venation and armed pleats on the leaves that characterized the latter. Furthermore, $B$. toei has a syncarp with fewer and smaller drupes (160 drupes of $15-18 \mathrm{~mm}$ long vs $240-430$ drupes of $20-25 \mathrm{~mm}$ in B. humilis). Benstonea toei was strangely omitted from STONE's (1978) revision of Pandanus subg. Acrostigma. 
47. Benstonea tunicata (B. C. Stone) Callm. \& Buerki, comb. nova.

$\equiv$ Pandanus tunicatus B. C. Stone in Malaysian J. Sci. 3A: 70. 1975.

Typus: Malaysia. Sabah (Borneo): Mt Kinabalu, S slope, 11.IV.1973, Stone \& al. 11437 (holo-: PH [PH000 18607] image seen; iso-: K [K000781395]!, SING [SING0 059102]!).

Distribution and ecology. - Benstonea tunicata is confined to montane rainforests of Mt. Kinabalu in Sabah (Borneo) (STONE, 1975a).

48. Benstonea undulifolia (Holttum \& H. St. John) Callm. \& Buerki, comb. nova.

$\equiv$ Pandanus undulifolius Holttum \& H. St. John in Pacific Sci. 16: 221. 1962.

Typus: MalaYSIA. Johore: Sungei Kayu, Mawai-Jamaluang rd., 11.X.1936, Corner 32477 (holo-: SING [SING00 59103]!; iso-: K [K000781312]!, SING [SING0059104]!).

Distribution and ecology. - Benstonea undulifolia is known only from lowland swampy rainforest of Johore in Peninsular Malaysia (STONE, 1978).

49. Benstonea unguiculata (Ridl.) Callm. \& Buerki, comb. nova.

$\equiv$ Pandanus unguiculatus Ridl., Mat. Fl. Malay. Penins. 2: 229. 1907.

Typus: Malaysia. Selangor (Peninsular Malaysia): Gunung Kutu, V.1896, Ridley 7659 (holo-: SING [SING00 59105]!).

Distribution and ecology. - Benstonea unguiculata is endemic to lowland rainforests of Peninsular Malaysia from sea level to $1500 \mathrm{~m}$ (Stone, 1978).

50. Benstonea vriensii (Martelli) Callm. \& Buerki, comb. nova.

$\equiv$ Pandanus vriensii Martelli in Webbia 4: 433. 1914.

Typus: Indonesia. Sumatra: Battakbergen, I.1905, De

Vriens s.n. (holo-: FI [FI003944: 3 sheets] images seen).

Distribution and ecology. - Benstonea vriensii is confined to the lowland rainforests of Sumatra (Indonesia) (STONE, 1978).

\section{Acknowledgments}

We are indebted to all the people who helped with material in herbaria around the world, without whom this study would not have been possible: Chiara Nepi (Museo di Storia Naturale, Università di Firenze, Italy), Yong Kien Thai (Rimba Ilmu Botanical Garden, University of Malaya, Kuala-Lumpur), Serena Lee (Singapore Botanic Garden), Nicolien Sol (Leiden Herbarium), Fred Stauffer, Nicolas Fumeaux, Carlo Müller and Laurent Gautier (Conservatoire et Jardin botaniques de la Ville de Genève [CJBG]), William Baker and Lauren Gardiner (Royal Botanic Gardens, Kew), Napua Harbottle (Bishop Museum, Honolulu), Hajo Esser and Christian Bräuchler (Botanische Staatssammlung München), Elspeth Haston (Royal Botanic Garden Edinburgh), Lin Ingrid Pol-Yin and Rusty Russell (United States National Herbarium, Washington), Ewindstaël Ramanantsoa, Sabine Comtet, Odile Poncy, Bérangère Offroy and Thomas Haevermans (Muséum national d'Histoire naturelle, Paris), Ulrike Stark and Robert Vogt (Botanischer Garten und Botanisches Museum Berlin-Dahlem, Berlin), Emily Wood (Harvard University Herbaria) and Andrew S. Doran (University of California, Berkeley). We are very grateful to people that helped in the field: Tony O'Dempsey (Singapore), Hassam Ibrahim (National Parks, Singapore), Marika Tuiwawa and Alifereti Naikatini (University of South Pacific, Suva, Fiji), Laure Barrabé and Jérôme Munzinger (IRD, Nouméa, New Caledonia), Sharon Christoph and Chris Davidson (Boise, Idaho, U.S.A.), Joan Pereira, Postar Miun, Jeisin Jumian and Nur Adillah (Sabah Forestry Department, Sandakan, Sabah, Malaysia) and Mohizah Mohamad, Yahul Bin H. J. Wat and Aon Ak Ginin (Sarawak Forestry Department, Kuching, Sarawak, Malaysia); to the National Parks and Nature Reserves Forest Department in Sarawak, the Sabah Biodiversity Centre (Malaysia), the Biodiversity Information \& Policy Section, National Biodiversity Centre, National Parks (Singapore), and the Ministry of Education, Youth \& Sports and Culture, National Heritage \& Arts in Suva (Fiji) for providing collecting and export permits for this research; to Ary Keim (Herbarium Bogoriense, Bogor, Indonesia) and Matthew Jebb (National Botanic Gardens, Dublin) for fruitful discussions on Pandanaceae; and to Peter Phillipson (Missouri Botanical Garden [MBG]) and Pierre-André Loizeau (CJBG) for their constant support in our research. We are very grateful to Patrick Perret, editor of Candollea, for his careful review of this manuscript and Roy Gereau (MBG) for suggesting the generic name. Financial support to MWC was provided by the Swiss National Foundation (grant \# IZK0Z3_140186), the National Geographic Society (grant \# 9042-11) and by the Muséum national d'Histoire naturelle as a Chercheur Invité fellowship, and to SB through a Marie-Curie Intra-European Fellowship (CRADLE; no 253866). Finally, we are very grateful to the Idaho Botanical Research Foundation for their generous support of fieldwork in Borneo, Fiji and Singapore. 


\section{References}

Balfour, B. (1878). Observations on the genus Pandanus (ScrewPines); with an enumeration of all species described or named in books, herbaria, and nurserymen's catalogs; together with their synonyms and native countries so far as these have been ascertained. J. Linn. Soc., Bot. 27: 33-67.

Brongniart, A. (1875). Observations sur les Pandanées de la Nouvelle-Calédonie. Ann. Sci. Nat. ser. 6, 1: 262-293.

Buerki, S., M. W. Callmander, D. S. Devey, L. Chapell, T. GalLAHer, J. Munzinger, T. HAevermans \& F. Forest (2012). Straightening out the screw-pines: a first step in understanding phylogenetic relationships within Pandanaceae. Taxon 61: 1010-1020.

Callmander, M. W. (2000). Pandanus subg. Martellidendron (Pandanaceae) part 1: New findings on Pandanus hornei Balf. f. (sect. Seychellea) from the Seychelles. Webbia 55: 317-329.

Callmander, M. W. (2001). Pandanus subg. Martellidendron (Pandanaceae) part II: revision of sect. Martellidendron Pic. Serm. in Madagascar. Bot. J. Linn. Soc. 137: 353-374.

CAllmander, M. W., P. Chassot, PH. KüPfer \& P. P. Lowry II (2003). Recognition of Martellidendron, a new genus of Pandanaceae, and its biogeographic implications. Taxon 52: 747-762.

Callmander, M. W., S. Wohlhauser \& M. O. Laivao. (2001). Une nouvelle section du genre Pandanus (Pandanaceae) à Madagascar: Pandanus sect. Tridentistigma. Adansonia ser. 3, 23: 49-57.

DE VRIESE, W. H. (1854). Remarks on Doornia and Rykia, two new genera of Screw-Pines. Hooker J. Bot. Kew Gard. Misc. 6: 257-268.

GAUDICHAUD, C. (1841). Voyage autour du monde executé pendant les années 1836-1837 sur la corvette «La Bonite» comandée par M. Vaillant. Botanique. Atlas. Arthus Bertrand, Paris.

HuYNH, K.-L. (1974). La morphologie microscopique de la feuille et la taxonomie du genre Pandanus I. Aperçu général sur les caractères micromorphologiques de la feuille du genre Pandanus et leur valeur taxonomique. Bot. Jahrb. Syst. 94: 190-256.

HuYNH, K.-L. (1975). La morphologie microscopique de la feuille et la taxonomie du genre Pandanus II. Le sous-genre Rykia. Bot. Jahrb. Syst. 95: 106-148.

HuYNH, K.-L. (1976). La morphologie microscopique de la feuille et la taxonomie du genre Pandanus III. Le sous-genre Lophostigma. Bot. Jahrb. Syst. 97: 72-119.

HuYNH, K.-L. (1977). La morphologie microscopique de la feuille et la taxonomie du genre Pandanus IV. Le sous-genre Kurzia. Bot. Jahrb. Syst. 98: 199-249.

HuYNH, K.-L. (1979). La morphologie microscopique de la feuille et la taxonomie du genre Pandanus VI. P. subg. Vinsonia et P. subg. Martellidendron 1. Partie systématique. Bot. Jahrb. Syst. 100: 473-517.

HuYnH, K.-L. (1980). Quelques espèces de Pandanus (Pandanaceae) peu connues des archipels des Philippines, de Palaos et de Salomon. Candollea 35: 385-419.

HuYNH, K.-L. (1982). La fleur mâle de quelques espèces de Pandanus subg. Lophostigma (Pandanaceae) et sa signification taxonomique, phylogénique et évolutive. Beit. Biol. Pflanzen 57: 15-83.
Huynh, K.-L. (1991). New data on the taxonomic position of Pandanus eydouxia (Pandanaceae), a species of the Mascarene Islands. Bot. Helv. 101: 29-37.

HuYNH, K.-L. (2001). Contribution to the flower structure of Sararanga (Pandanaceae). Bot. J. Linn. Soc. 136: 239-245.

JebB, M. (1992). A field guide to Pandanus in New Guinea, the Bismarck Archipelago \& the Solomon Islands. Christensen Research Institute, Madang.

KANeHIRA, R. (1940). A summary of our knowledge of Papuan Pandanus. Bot. Mag. (Tokyo) 54: 249-260.

KeIM, A. P. (2009a). Pandanaceae of the Island of Yapen, Papua (West New Guinea), Indonesia, with their nomenclature and notes on the rediscovery of Sararanga sinuosa, and sevarl new species and records. Blumea 54: 255-266.

KeIM, A. P. (2009b). New species of Pandanus (Pandanaceae) from Kabaena Island, south east Sulawesi. Reinwardtia 13: 13-14.

KeIM, A. P. (2012). The Pandan flora of Foja-Mamberamo game reserve and Baliem Valley, Papua-Indonesia. Reinwardtia 13: 271-297.

KuRZ, S. (1867). Revision of the Indian Screwpines and their Allies. J. Bot. 5: 93-106; 125-136.

Laivao, M. O., M. W. Callmander \& S. Buerki (2006). Sur les Pandanus (Pandanaceae) à stigmates saillants de la côte Est de Madagascar. Adansonia ser. 3, 28: 267-285.

Martelli, U. (1904). Pandani asiatici nuovi. Bull. Soc. Bot. Ital. 1904: 298-304.

Martelli, U. (1913). Enumerazione delle «Pandanaceae». II. Pandanus. Webbia 4 : 5-40.

MARTELli, U. (1914). Le specie e varietà nuove di «Pandanus» menzionate nella enumerazione delle Pandanaceae. Webbia 4: 399-435.

ROXBURG, W. (1832). Flora Indica or descriptions of Indian plants. 3. Calcutta \& London.

Solms-Laubach, H. (1878). Monographia Pandanacearum. Linnaea 42: $1-110$.

St. John, H. (1960). Revision of the genus Pandanus Stickman, Part 1. Keys to the sections. Pacific Sci. 14: 224-241.

St. John, H. (1963). Revision of the genus Pandanus Stickman, Part 15. Malaysian species decribed by H. N. Ridley. Pacific Sci. 17: 329-360.

ST. John, H. (1965). Revision of the genus Pandanus Stickman, Part 19. Additional Malayan species of Pandanus. Pacific Sci. 19: 224237-360.

St. John, H. (1969). Revision of the genus Pandanus Stickman, Part 34. Four species from the Philippines. Pacific Sci. 23: 355-366.

St. John, H. (1975). Revision of the genus Pandanus Stickman, Part 38. Pandanus in Fiji, first group (except section Pandanus). Pacific Sci. 29: 55-77.

Stone, B. C. (1968a). Pandanus Stickm. in the Malayan Peninsula, Singapore, and lower Thailand. Part IV. Malay. Nat. J. 21 : 125-141.

Stone, B. C. (1968b). Studies in the Malesian Pandanaceae, II. Two new species of Pandanus Stickm. Sect. Fusiforma St. John. Reinwardtia $7:$ 411-420.

Stone, B. C. (1969). Studies in the Malesian Pandanaceae, VI. The identity of "Pandanus pilaris" Ridley. Webbia 23: 609-613. 
Stone, B. C. (1971a). Studies in the Malesian Pandanaceae, VIII. Some new and little known sections of Pandanus. Fed. Mus. J. 13: 138-149

Stone, B. C. (1971b). A Preliminary survey of the Pandanaceae of Thailand and Cambodia. Nat. Hist. Bull. Siam Soc. 24: 1-32.

Stone, B. C. (1972). Studies in the Malesian Pandanaceae X. Four new Malesian species of Pandanus and observations on P. sarawakensis. Fed. Mus. J. 14: 127-136.

Stone, B. C. (1974). Toward an improved infra-generic classification in Pandanus (Pandanaceae). Bot. Jahrb. Syst. 94: 459-540.

Stone, B. C. (1975a). Studies in Malesian Pandanaceae XV. Two new species of Pandanus from Mt. Kinabalu, Sabah (Borneo) and notes on the Pandanaceae of Mt. Kinabalu. Malay. J. Sci. 3: 69-74.

Stone, B. C. (1975b). Notes on the Pandanaceae of Ceylon, with a review of the species cultivated in the Royal Botanic Gardens, Peradeniya and those found in its herbarium. Ceylon J. Sci. (Bio. Sci.) 11: 36-42.

Stone, B. C. (1978). Revisio Pandanacearum, Part I. Pandanus subgenera Coronata and Acrostigma. Flora Malesiana precursores. Fed. Mus. J. 23: 1-74.

Stone, B. C. (1982a). New Guinea Pandanaceae: first approach to ecology and biogeography. In: GRESSITT, J. L. (ed.), Ecology and Biogeography of New Guinea. Mono. Biol. 42: 401-436.

Stone, B. C. (1982b). Two new species of Pandanus from Gunung Mulu National Park. In: Jeremy A.C \& M. Kavanaugh (ed), Notulae et Novitates Muluensis. Bot. J. Linn. Soc. 85: 31-36

Stone, B. C. (1983a). Some new and critical Pandanus species of subgenus Acrostigma, I. Supplement to Revisio Pandanacearum. Gard. Bull. Singapore 36: 205-212.

Stone, B. C. (1983b). Pandanaceae. In: AubrÉville, A. \& J.-F. Leroy (ed.), Fl. Cambodge Laos Vietnam 20: 1-48. Muséum national d'Histoire naturelle, Paris.

Stone, B. C. (1983c). Studies in Malesian Pandanaceae, 19. New species of Freycinetia and Pandanus from Malesia and Southeast Asia. J. Arnold Arbor. 64: 309-324.

Stone, B. C. (1990). New evidence for the reconciliation of floral organisation in Pandanaceae with normal angiosperm patterns. In: BaAs P. (ed.), Plant Diversity in Malaysia: 33-55. Kluwer Academic Publishers, Holland.

Stone, B. C. (1993). Studies in the Malesian Pandanaceae 21. The genus Pandanus in Borneo. Sandakania 2: 35-84.

Stone, B. C., K.-L. Huynh \& H. H. Poppendeck (1998). Pandanaceae. In: KUBITZKI, K. The families and genera of flowering plants 3 : 397-404. Springer. Berlin.

WALLICH, N. (1831). A numerical list of dried plants in the East India Company's Museum. London.

Wallich, N. (2005). Brief Excursion to the Hills to the East of Ava in November 1826. SOAS Bulletin of Burma Research 3: 476-482.

Warburg, O. (1900). Pandanaceae. In: ENGLeR, A. (ed.), Das Planzenreich 3(IV, 9): 1-97. Leipzig, Engelmann, Germany.

Wilson, A. J. G. (2011). Pandanaceae. In: Wilson, A. J. G. (ed.), Fl. Australia 39: 211-235. 
Appendix 1. - Complete list of accepted names in Benstonea Callm. \& Buerki with synonyms (incl. basionyms).

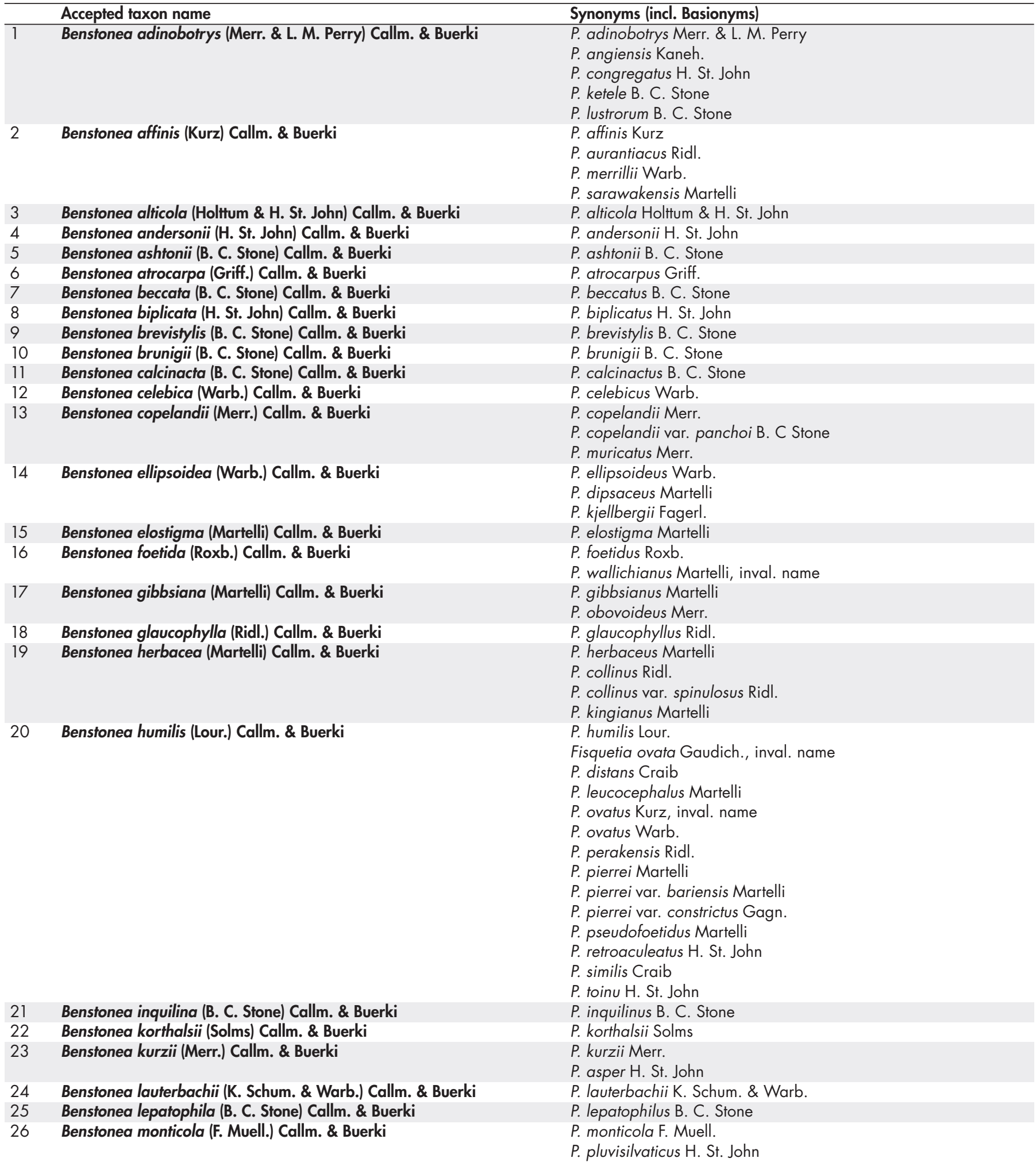




\begin{tabular}{|c|c|c|}
\hline 27 & Accepted taxon name & Synonyms (incl. Basionyms) \\
\hline 28 & Benstonea odoardii (Martelli) Callm. \& Buerki & $\begin{array}{l}\text { P. odoardii Martelli } \\
\text { P. eumekes B. C. Stone } \\
\text { P. humicola Kaneh. } \\
\text { P. ihuanus Martelli } \\
\text { P. inokumae Kaneh. } \\
\text { P. papuanus Ridl., illeg. name } \\
\text { P. pentagonos H. St. John } \\
\text { P. rostellatus Merr. \& L. M. Perry }\end{array}$ \\
\hline 29 & Benstonea ornata (Solms) Callm. \& Buerki & $\begin{array}{l}\text { P. ornatus Solms } \\
\text { Fisquetia ornata Gaudich., inval. name } \\
\text { P. monotheca Martelli } \\
\text { P. ornatus Kurz, inval. name } \\
\text { P. ornatus f. spicatus Martelli } \\
\text { P. recurvatus H. St. John }\end{array}$ \\
\hline 32 & Benstonea pectinata (Martelli) Callm. \& Buerki & $\begin{array}{l}\text { P. pectinatus Martelli } \\
\text { P. papilio B. C. Stone }\end{array}$ \\
\hline 33 & Benstonea permicron (Kaneh.) Callm. \& Buerki & P. permicron Kaneh. \\
\hline 34 & Benstonea pilaris (Ridl.) Callm. \& Buerki & P. pilaris Ridl. \\
\hline 35 & Benstonea poronavila (B. C. Stone) Callm. \& Buerki & P. poronavila B. C. Stone \\
\hline 36 & Benstonea pseudosyncarpa (Kaneh.) Callm. \& Buerki & P. pseudosyncarpus Kaneh. \\
\hline 37 & Benstonea pumila (H. St. John) Callm. \& Buerki & P. pumilus $\mathrm{H}$. St. John \\
\hline 38 & Benstonea rupestris (B. C. Stone) Callm. \& Buerki & $\begin{array}{l}\text { P. rupestris B. C. Stone } \\
\text { P. scandens B. C. Stone } \\
\text { P. oresbios B. C. Stone }\end{array}$ \\
\hline 39 & Benstonea rustica (B. C. Stone) Callm. \& Buerki & P. rusticus B. C. Stone \\
\hline 42 & Benstonea sylvatica (B. C. Stone) Callm. \& Buerki & P. sylvaticus B. C. Stone \\
\hline 43 & Benstonea thomissophylla (B. C. Stone) Callm. \& Buerki & P. thomissophyllus B. C. Stone \\
\hline 44 & Benstonea thurstonii (C. H. Wright) Callm. \& Buerki & $\begin{array}{l}\text { P. thurstonii C. H. Wright } \\
\text { P. varawa H. St. John }\end{array}$ \\
\hline 45 & Benstonea thwaitesii (Martelli) Callm. \& Buerki & $\begin{array}{l}\text { P. thwaitesii Martelli } \\
\text { P. foetidus var. racemosus Trimen }\end{array}$ \\
\hline 46 & Benstonea toei (H. St. John) Callm. \& Buerki & P. toei H. St. John \\
\hline 47 & Benstonea tunicata (B. C. Stone) Callm. \& Buerki & P. tunicatus B. C. Stone \\
\hline 48 & Benstonea undulifolia (Holttum \& H. St. John) Callm. \& Buerki & P. undulifolius Holttum \& H. St. John \\
\hline 49 & Benstonea unguiculata (Ridl.) Callm. \& Buerki & $\begin{array}{l}\text { P. unguiculatus Ridl. } \\
\text { P. attenuatus } \mathrm{H} \text {. St. John } \\
\text { P. caudatifolius H. St. John } \\
\text { P. globuliferus Ridl. } \\
\text { P. globulosus H. St. John }\end{array}$ \\
\hline 50 & Benstonea vriensii (Martelli) Callm. \& Buerki & P. vriensii Martelli \\
\hline
\end{tabular}

